\title{
Clinical Manifestations of Impaired GnRH Neuron Development and Function
}

\author{
Hyung-Goo Kim ${ }^{\text {a }}$ Balasubramanian Bhagavath ${ }^{\mathrm{b}}$ Lawrence C. Layman $^{\mathrm{a}}$ \\ aSection of Reproductive Endocrinology, Infertility, and Genetics, Department of Obstetrics and Gynecology, \\ Reproductive Medicine Program, Developmental Neurobiology Program, Institute of Molecular Medicine and \\ Genetics, Neuroscience Program, Medical College of Georgia, Augusta, Ga., and ${ }^{b}$ Division of Reproductive \\ Endocrinology and Infertility, Women and Infants' Hospital of Rhode Island, Brown University, Providence, R.I., USA
}

\section{Key Words}

Gonadotropin-releasing hormone $\cdot \mathrm{GnRH}$ neuron

migration · Olfactory neuron migration · Gonadotropin

deficiency $\cdot$ Hypogonadism $\cdot$ Idiopathic hypogonadotropic

hypogonadism $\cdot$ Kallmann syndrome

\begin{abstract}
Gonadotropin-releasing hormone $(\mathrm{GnRH})$ and olfactory neurons migrate together in embryologic development, and disruption of this process causes idiopathic hypogonadotropic hypogonadism $(\mathrm{IHH})$ with anosmia (Kallmann syndrome (KS)). Patients with $\mathrm{IHH} / \mathrm{KS}$ generally manifest irreversible pubertal delay and subsequent infertility due to deficient pituitary gonadotropins or $\mathrm{GnRH}$. The molecular basis of $\mathrm{IHH} / \mathrm{KS}$ includes genes that: (1) regulate $\mathrm{GnRH}$ and olfactory neuron migration; (2) control the synthesis or secretion of $\mathrm{GnRH}$; (3) disrupt GnRH action upon pituitary gonadotropes, or (4) interfere with pituitary gonadotropin synthesis or secretion. KS patients may also have midline facial defects indicating the diverse developmental functions of genes involved. Most causative genes cause either normosmic IHH or KS except FGFR1, which may cause either phenotype. Recently, several balanced chromosomal translocations have been identified in $\mathrm{IHH} / \mathrm{KS}$ patients, which could lead to the identification of new disease-producing genes. Although there are two cases reported who have digenic disease, this awaits confirmation
\end{abstract}

in future larger studies. The challenge will be to determine the importance of these genes in the $10-15 \%$ of couples with normal puberty who have infertility.

Copyright ๑ 2008 S. Karger AG, Basel

\section{Introduction}

Reproductive function in humans depends upon the coordinated interaction of the hypothalamic-pituitarygonadal axis directed by gonadotropin-releasing hormone $(\mathrm{GnRH})$. GnRH is a decapeptide that is released from $\mathrm{GnRH}$ neurons in a pulsatile fashion into the hypophyseal-portal circulation, the capillaries of which perfuse the anterior pituitary gland. GnRH binds to the GnRH receptor, a G-protein coupled receptor on the cell surface of the gonadotropes, which then in turn synthesize and secrete the gonadotropins luteinizing hormone (LH) and follicle-stimulating hormone (FSH). The pituitary gonadotropins are released into the circulation, where they stimulate gonadal steroidogenesis and gametogenesis (fig. 1). The production of gonadal steroids, principally testosterone in males and estradiol in females, has negative feedback effects upon the hypothalamus and pituitary. A variety of peptide hormones including inhibin A and B, follistatin, as well as growth factors are also involved in this complex endocrine axis.

\section{KARGER}

Fax +4161306 1234 E-Mail karger@karger.ch www.karger.com
(C) 2008 S. Karger AG, Basel

$1424-862 X / 08 / 0163-0165 \$ 24.50 / 0$

Accessible online at:

www.karger.com/nsg
Lawrence C. Layman, MD

Section of Reproductive Endocrinology, Infertility, and Genetics

Department of Obstetrics and Gynecology, The Medical College of Georgia

1120 15th Street, Augusta, GA 30912-3360 (USA)

Tel. +1 706721 3832, Fax +1 706 7216830,E-Mail llayman@mcg.edu 


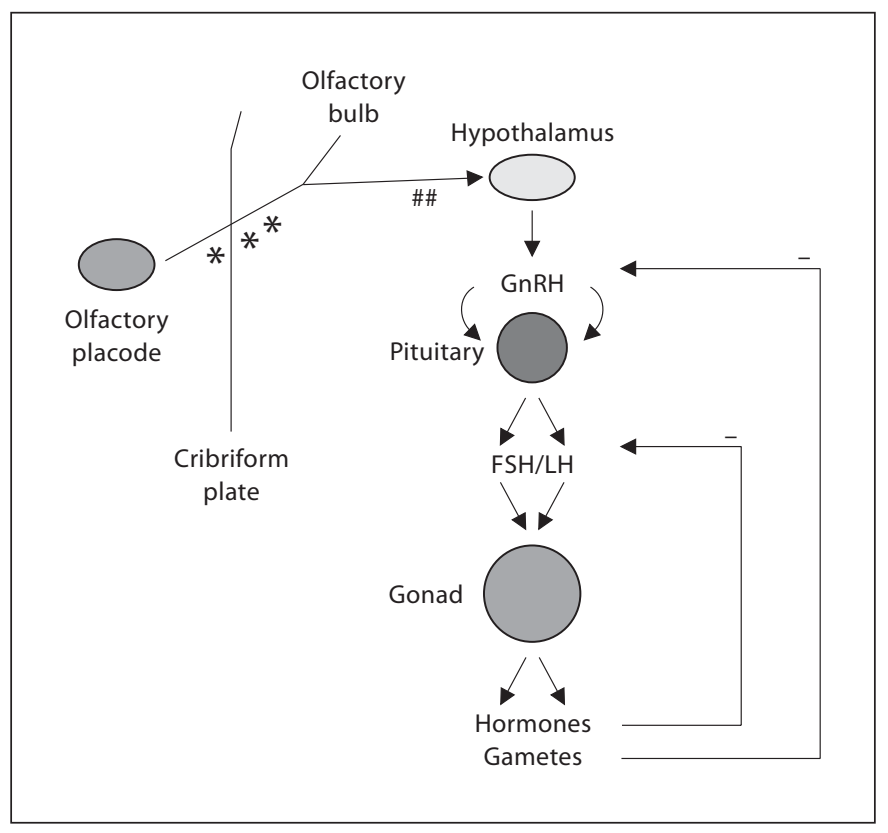

Fig. 1. Embryologic development of the GnRH pulse generator and the hypothalamic-pituitary-gonadal axis. Olfactory and GnRH neurons travel from the olfactory placode region to cross the cribriform plate. Some olfactory neurons go dorsally to the olfactory bulb, while others with GnRH neurons go ventrally to the forebrain which will become the hypothalamus. The location of migratory GnRH neurons (NLT and GN11) are indicated by *** while the postmigratory hypothalamic GT1-7 cells are indicated by \#\#. The negative sign (-) indicates negative feedback of sex steroids on the hypothalamic-pituitary axis.

Defects in the development of the hypothalamus, impairment of GnRH and olfactory neuron migration, and deficient GnRH secretion and/or action not only would be predicted to have detrimental effects upon pubertal development and fertility, but have been demonstrated to do so in humans. Mutations in genes affecting GnRH neuroendocrine function demonstrate the importance of these particular genes in normal human reproductive function.

\section{Factors Governing GnRH and Olfactory Neuron Migration}

In teleost fish and mammalian embryological development, GnRH neurons migrate with olfactory neurons from the olfactory placode region to their normal position in the hypothalamus [1]. The vomeronasal nerve originates outside the brain and travels from the olfac- tory epithelium to cross the cribriform plate and then sends fibers dorsally to the olfactory bulb (fig. 1). The caudal vomeronasal nerve traverses more ventrally with $\mathrm{GnRH}$ neurons into the forebrain region that becomes the hypothalamus. The specific details of the precise regulation of GnRH and olfactory neuron migration are unknown, but experimental evidence supports the involvement of a number of factors. The netrin signaling system has been implicated in GnRH neuron migration since both of the knockout mouse models for the ligand netrin1 and one of its receptors - deleted in colorectal carcinoma (DCC) - demonstrate impaired GnRH neuron migration $[2,3]$. In addition, both netrin-1 and DCC are expressed in $\mathrm{GnRH}$ neuronal cell lines. Other factors known to affect GnRH neuron migration include: hepatocyte growth factor/scatter factor (HGF/SF), Gas6/Ark signaling, glycoconjugates, slit, gamma aminobutyric acid (GABA), as well as neural cell adhesion molecules and related proteins (tenascin, phosphacam, and laminin) [1].

Four factors appear to have clinical significance in humans, and these will be discussed in more detail below. There is evidence from both in vitro analyses and translational findings in human disease that both anosmin-1, encoded by the KAL1 gene, and fibroblast growth factor (FGF) signaling affect both olfactory and GnRH neuron migration. Mutations in these genes cause Kallmann syndrome, the combination of idiopathic hypogonadotropic hypogonadism (IHH) and anosmia (see below). There is also presumptive evidence that nasal embryonic LHRH factor (NELF) and chromodomain helicase DNAbinding protein 7 (CHD7) may cause Kallmann syndrome, but this is not as conclusively established as it is for KAL1 and FGFR1. The important embryologic event of $\mathrm{GnRH}$ and olfactory neuron migration illustrates the close interaction of the reproductive and olfactory systems, which when disturbed causes reproductive and olfactory dysfunction.

\section{In vitro Analysis of GnRH Neuron Migration}

Studying the functional effects of mutations upon $\mathrm{GnRH}$ neuron migration and function has been challenging because of the small number of $\mathrm{GnRH}$ neurons ( $~ 800$ in mice and 1,000-2,000 in primates), which are dispersed throughout the brain. The generation of two types of immortalized GnRH neurons has permitted the study of more immature, migratory neurons, as well as the mature, postmigratory GnRH neurons. To generate 
hypothalamic specific tumors, Mellon et al. [4] inserted the rat Gnrh1 promoter upstream of the SV40 T antigen and injected this construct into fertilized mouse eggs to produce transgenic mice. Hypothalamic tumors were identified, and the resulting nonmigratory GT1-7 cells were found to express and secrete pulsatile GnRH. Similarly, Radovick et al. [5] cloned the human GNRH1 promoter upstream of the $\mathrm{T}$ antigen. This time, the transgenic mice demonstrated tumors along the olfactory placode/olfactory region that did not cross the cribriform plate. These cells (NLT and GN11) are migratory, but secrete much less GnRH than the postmigratory GT1-7 cells (fig. 1). Although cell lines cannot fully recapitulate in vivo conditions, they provide a reasonable starting point to try to understand the mechanisms of GnRH action.

\section{The Ontogeny of GnRH Secretion}

Although GnRH neurons are dispersed throughout the central nervous system, the arcuate nucleus contains the $\mathrm{GnRH}$ neurons that appear to regulate puberty and reproduction. Since $\mathrm{GnRH}$ is secreted in a pulsatile fashion (with a very short half-life of 1-3 min) within the hypophyseal-portal system and directs the reproductive axis, this is often referred to as the ' $\mathrm{GnRH}$ pulse generator'. The activity of the GnRH pulse generator is reflected by changing gonadotropin levels during the human lifespan. In the human embryo, gonadotropins begin to rise at 10 weeks of gestation, peak in the second half of pregnancy, but then decline because of the negative feedback from placental steroids. After birth when gestational steroids are removed, both FSH and LH rise in the neonatal period and remain elevated for different times, which are sex-specific (the first 6 months in boys and the first 1-2 years in girls), with a subsequent decline during childhood until puberty ensues [6]. This decline in gonadotropin secretion appears to be central in origin since patients with gonadal failure have low/normal levels of gonadotropins during childhood prior to the time of puberty. Molecular mechanisms that control the initiation of puberty are incompletely understood, but evidence from human mutations suggests at least two different pathways - leptin and kisspeptin/GPR54 signaling are important in normal puberty.

About age 9 years, gonadotropins begin to rise, first $\mathrm{FSH}$, then $\mathrm{LH}$, which reflects the frequency of the GnRH pulse generator. Slower GnRH pulses appear to preferentially favor FSH secretion, while more rapid pulses favor
LH secretion. In early puberty, LH pulses are nocturnal, but subsequently occur throughout the 24-hour period. This increased pulsatile secretion of LH (along with FSH) stimulates gonadal sex steroid secretion, which then produces negative feedback upon the hypothalamus and pituitary gland [6]. In adult males, $\mathrm{LH}$ pulses occur roughly every $2 \mathrm{~h}$, but vary in adult females depending upon the time of the menstrual cycle. Typically pulses occur every $\sim 90$ min in the early follicular phase, but increase to hourly pulses near the LH surge. Following ovulation in the luteal phase, LH pulses slow down to every $2-4 \mathrm{~h}$.

\section{Normal Puberty}

Normal puberty is usually a progression of events, which when initiated, is typically completed in 3-4 years [7]. Adrenarche, the secretion of adrenal androgens (androstenedione, DHEA, and DHEAS), begins about 6-8 years of age and continues through the mid-teens in both sexes. In girls, breast development (thelarche) generally begins about age $8-9$ years, about the same time of pubic hair development (pubarche). A growth spurt occurs at 12 years of age, which on the descending arm of the growth spurt the first menstrual cycle (menarche) occurs $[7,8]$. In boys the initial pubertal event is testicular growth, which usually begins about 10.5 years of age when the testes are at least $2.5 \mathrm{~cm}$ in any dimension. Pubarche frequently starts simultaneously with testicular development, while axillary hair growth occurs at about the time of peak height velocity (age 14 years).

\section{Delayed Puberty}

\section{Overview of the Evaluation}

Delayed puberty is usually defined as the absence of signs of puberty by age 14 in boys and by the absence of breast development by age 13 or menarche by age 15 in girls. The etiology of delayed puberty is complex, and will not be detailed here. However, thyroid disease and hyperprolactinemia should be excluded in all patients, regardless of whether they are hypogonadal or not. In hypogonadal patients (males or females with low sex steroids), serum gonadotropins help classify the site of the HPG axis that is disrupted $[7,8]$. If $\mathrm{LH}$ and FSH are elevated on several occasions, the diagnosis is hypergonadotropic hypogonadism (or gonadal failure) and a karyotype is necessary to exclude chromosomal abnormalities (47,XXY or $46, \mathrm{XX}$ in males; $45, \mathrm{X}$ or a $46, \mathrm{XY}$ cell line in females). 


\section{Hypogonadotropic Hypogonadism}

Alternatively, if the patient with hypogonadism has low or normal FSH and LH, hypogonadotropic hypogonadism is present, signifying hypothalamic or pituitary dysfunction $[7,8]$. In these patients, a pituitary tumor, typically a prolactin-producing adenoma or a craniopharyngioma, must be excluded by MRI. Extreme weight loss/eating disorders, stress, and excessive exercise must be excluded, as shown by a number of chronic medical conditions (malignancy, renal disease, neurologic diseases, etc.). If these conditions are not present, the more reversible form of constitutional delay of puberty (CDP) must be differentiated from the more severe phenotype of isolated or idiopathic hypogonadotropic hypogonadism (IHH). If hypogonadotropic hypogonadism is present $\geq 17$ years for girls and $\geq 18$ years for boys, the diagnosis is IHH [9]. If there is impairment in olfaction (anosmia), then Kallmann syndrome (KS) is present. Combined pituitary hormone deficiency (CPHD) should be considered if extreme short stature is also present, since it could indicate severe pituitary failure with growth hormone and thyroid hormone deficiency.

\section{Clinical Features of Idiopathic Hypogonadotropic Hypogonadism and Kallmann Syndrome}

Although somewhat arbitrary and not always easy to determine clinically, IHH may be classified according to the severity of sex hormone deficiency. Without any evidence of sexual development, the patient may be classified as complete $\mathrm{IHH}$, and if there is some evidence of puberty, incomplete IHH [10]. This distinction must be determined prior to the patient ever receiving hormone therapy. Females with no breast development (Tanner stage I) and males with testes $\leq 3 \mathrm{~cm}^{3}$ have complete $\mathrm{IHH}$, while those females with some evidence of breast development and males with testes $>3 \mathrm{~cm}^{3}\left(15-25 \mathrm{~cm}^{3}\right.$ normal) have incomplete IHH. This sub-classification has been reported to be more valuable than endocrinological studies since gonadotropins and serum sex steroid levels do not differentiate between the complete and incomplete forms of IHH [10].

A variety of somatic anomalies may also be associated with hypogonadotropic hypogonadism such as anosmia/ hyposmia, cleft palate, dental agenesis, visual abnormalities, deafness, mental retardation, renal agenesis, pes cavus, and neurologic abnormalities such as cerebellar dysfunction and synkinesia. Since some patients with CHARGE syndrome (coloboma of the eye, heart defects, choanal atresia, retardation in growth and development, genitourinary abnormalities, ear anomalies) appear to have anosmia and endocrine studies suggestive of IHH/ KS, these anomalies must also be considered (see below). $\mathrm{IHH} / \mathrm{KS}$ may be associated with a variety of chromosomal abnormalities and other Mendelian disorders, thereby complicating the understanding of this diagnostic entity.

Treatment of IHH/KS involves the use of either estrogen for breast development in women or testosterone in men for secondary sex characteristics. When fertility is desired, pulsatile GnRH may be administered, but in practice, it is more common to use gonadotropins (both FSH and LH) for ovulation induction in women and for spermatogenesis in men. Generally, women ovulate and their cycle fecundity is normal for their age. For men, treatment usually takes 6-12 months, but improvements in sperm production are evident in most men [11]. Although $\mathrm{IHH} / \mathrm{KS}$ has always been thought to be irreversible and lifelong steroid hormone treatment was advocated (except when considering pregnancy), it has recently been reported that perhaps as many as $10 \%$ of men with IHH or KS may resume LH pulsatility and normalize their testosterone levels when treatment is discontinued [12].

\section{Molecular Basis of IHH}

\section{Pedigree Structure}

The prevalence of IHH/KS in the general population is unknown, but is estimated to be $1 / 10,000$ males and $1 / 40,000$ females. Likewise the proportion of familial cases is unclear and probably affected by the method of ascertainment. Waldstreicher et al. [13] found that $18 \%$ of 106 unrelated $\mathrm{IHH}$ probands had $\geq 1$ affected family members with IHH, but this was increased to $34 \%$ if reversible delayed puberty or isolated anosmia in family members were included. Quinton et al. [14] studied 215 IHH patients from three different London hospitals, and found familial transmission in $24 \%$ patients. However, Bhagavath et al. [15] found that only $6.3 \%$ of 315 unrelated IHH patients had a family member affected with $\mathrm{IHH} / \mathrm{KS}$. In all three of these studies, inheritance patterns included X-linked recessive, autosomal recessive, autosomal dominant [13-15].

\section{Chromosome Rearrangements}

Normal management of patients with $\mathrm{IHH} / \mathrm{KS}$ does not usually include a karyotype unless there is suspicion for Prader-Willi syndrome (60-70\% have a deletion 
Table 1. Reported chromosomal rearrangements with IHH/KS

\begin{tabular}{|c|c|c|}
\hline Chromosomal rearrangement & Phenotype & Author \\
\hline $\mathrm{t}(7 ; 12)(\mathrm{q} 22, \mathrm{q} 24)$ & KS & Best et al., 1991 [178] \\
\hline $\mathrm{X} ; \mathrm{Y}$ & KS & Guioli et al., 1992 [179] \\
\hline $\mathrm{t}(3 ; 9)(9 ; 12)(\mathrm{q} 13.2 ; \mathrm{q} 21.2 \mathrm{p} 13 ; \mathrm{q} 15)$ & KS & Casamassima et al., 1993 [180] \\
\hline $\mathrm{t}(13 ; 16)(\mathrm{q} 14.11 ; \mathrm{q} 24)$ & $\mathrm{IHH}$ & Kikuchi et al., 1993 [181] \\
\hline $\mathrm{t}(4 ; 12)(\mathrm{q} 25 ; \mathrm{q} 24.2)$ & hypogonadism? & Elbistan et al., 1994 [182] \\
\hline $\mathrm{t}(1 ; 10)(\mathrm{q} 44 ; \mathrm{q} 26)$ & $\mathrm{KS}$ & Schinzel et al., 1995 [183] \\
\hline $\begin{array}{l}46, X Y, \operatorname{inv}(3)(\mathrm{q} 24 \mathrm{q} 26.32), \mathrm{t}(3 ; 13 ; 18) \\
(\mathrm{q} 26.32 ; \mathrm{q} 21.2 ; \mathrm{q} 12.2)\end{array}$ & KS & Kroisel et al., 2000 [184] \\
\hline del8p11.2 & KS; spherocytosis & Vermeulen et al., 2002 [185] \\
\hline $\begin{array}{l}\text { 46,XY,inv }(10)(\mathrm{p} 15.2 \mathrm{q} 11.22) . \operatorname{ish} \operatorname{inv}(10) \\
(\mathrm{p} 15.2 \mathrm{q} 21.3)(\mathrm{p} 15 \times 3),(\mathrm{q} 21 \times 3)(\mathrm{p} 15 \text { conq } 21 \times 2)\end{array}$ & $\mathrm{IHH}$ & Helszer et al., 2003 [186] \\
\hline$(\mathrm{X})(\mathrm{p} 11.4 \mathrm{q} 11.2)$ & $\mathrm{IHH}$ & Talaban et al., 2005 [187] \\
\hline $46, \mathrm{XY}, \mathrm{t}(7 ; 8)(\mathrm{p} 12.3 ; \mathrm{p} 11.2)$ & $\mathrm{IHH}$ & Kim et al., 2005 [188] \\
\hline $46, \mathrm{XY}, \mathrm{t}(10 ; 12)(\mathrm{q} 26.3 ; \mathrm{q} 13.1)$ & KS & Bhagavath et al., 2006 [15] \\
\hline $46, \mathrm{XY}, \operatorname{mos} \mathrm{t}(3 ; 12)(\mathrm{p} 13 ; \mathrm{p} 13)[18] / 46, \mathrm{XY}[3]$ & IHH and cerebellar ataxia & Bhagavath et al., 2006 [15] \\
\hline $46, \mathrm{XY} / 46, \mathrm{X}, \operatorname{inv}(\mathrm{Y})(\mathrm{p} 11.2 \mathrm{q} 11.2)$ & $\mathrm{IHH}$ & Bhagavath et al., 2006 [15] \\
\hline
\end{tabular}

15q11-q13) or there are multiple congenital anomalies. Although some chromosomal translocations have been reported in IHH patients (table 1), no systematic study was performed until recently when 3/76 (4\%) of IHH patients were found to have chromosomal abnormalities [15]. Of $76 \mathrm{IHH} / \mathrm{KS}$ patients studied, 73 were normal (54 46,XY and 19 46,XX). However, three males without a family history of $\mathrm{IHH} / \mathrm{KS}$ had chromosome abnormalities: 46,XY,t(10;12)(q26.3;q13.1); 46,XY/46,X,inv(Y) (p11.2q11.2), and mos46,XY,t(3;12)(p13;p13)[18]/46,XY [3]. Balanced translocations may or may not cause the disorder [15], but provide valuable information for positional cloning of new $\mathrm{IHH} / \mathrm{KS}$ genes.

\section{Mendelian Forms of IHH}

Mutations in the KAL1, GNRHR, and FGFR1 genes account for most of the known cases of IHH/KS so the genotype/phenotype correlations will be discussed in more detail. However, all known molecular causes of $\mathrm{IHH} / \mathrm{KS}$ published in peer-reviewed journals will also be reviewed (table 2). To date, KAL1 gene mutations have been exclusively identified in anosmic males with KS, and GNRHR mutations have only been identified in normosmic IHH patients [16]. Although the molecular pathways of KS and normosmic IHH were initially thought to be independent, this has now been brought into question since fibroblast receptor-1 (FGFR1) mutations appear to cause both KS and IHH [17]. Two additional genes, nasal embryonic LHRH factor (NELF) and chromodomain helicase DNA-binding protein 7 (CHD7) appear to be prom- ising candidates for mutations in KS, which, if true, would increase the number of known genes causing $\mathrm{KS}$ to be four - KAL1, FGFR1, NELF, and CHD7.

\section{KAL1}

Men and women with KS demonstrate IHH and anosmia, further supporting the common developmental pathway of GnRH and olfactory neurons. Mutations in the KAL1 gene on chromosome Xp22.3 were first described in males with X-linked recessive KS $[18,19]$. The KAL1 gene spans $\sim 203 \mathrm{~kb}$ of genomic sequence, contains 14 exons, and has a homologous pseudogene on the $\mathrm{Y}$ chromosome. KAL1 encodes anosmin-1, a putative neural cell adhesion molecule which appears to be involved in the migration of $\mathrm{GnRH}$ and olfactory neurons during embryologic development. Deletions were first identified in males with multiple congenital anomalies including KS with a contiguous gene deletion syndrome including the KS locus $[18,19]$. Subsequently, intragenic deletions [20] and point mutations [21] were identified in KS patients, confirming that KAL1 mutations were causative.

The KAL1 gene has been cloned in a variety of species including Drosophila, Caenorhabditis elegans, zebrafish, and chicken, but surprisingly has not yet been identified in mice, despite the fact that the human antibody detects its presence [22]. Expression of KAL1 in both human and chick embryos demonstrates an excellent correlation to the tissues affected in KS patients. KAL1 mRNA has been identified in the olfactory bulb, retina, oculomotor nucleus, cerebellum, corticospinal tract, facial mesenchyme, 
Table 2. Gene mutations causing and suspected of causing IHH/KS in humans

\begin{tabular}{|c|c|c|c|}
\hline Gene & Localization & Phenotype & Inheritance \\
\hline \multicolumn{4}{|c|}{ GnRH neuron migration } \\
\hline KAL1 & $\mathrm{Xp} 22.3$ & KS & $\mathrm{X}$-linked recessive \\
\hline FGFR1 & 8p11.2-p11.1 & $\mathrm{KS}$ or $\mathrm{IHH}$ & autosomal dominant \\
\hline \multicolumn{4}{|c|}{ Hypothalamic function } \\
\hline GPR54 & $19 \mathrm{p} 13.3$ & $\mathrm{IHH}$ & autosomal recessive \\
\hline LEP & $7 q 31.3$ & obesity, IHH & autosomal recessive \\
\hline LEPR & $1 \mathrm{p} 31$ & obesity, IHH & autosomal recessive \\
\hline $\mathrm{NROB}^{*}$ & $\mathrm{Xp} 21$ & adrenal hypoplasia congenita and $\mathrm{IHH}$ & $\mathrm{X}$-linked recessive \\
\hline PCSK1 & $5 q 15-q 23$ & obesity, IHH & autosomal recessive \\
\hline \multicolumn{4}{|c|}{ Pituitary function } \\
\hline GNRHR & $4 q 21.2$ & $\mathrm{IHH}$ & autosomal recessive \\
\hline FSHB & $11 \mathrm{p} 13$ & isolated FSH deficiency & autosomal recessive \\
\hline LHB & $19 \mathrm{q} 13.3$ & isolated LH deficiency & autosomal recessive \\
\hline HESX1 & $3 \mathrm{p} 21.1-21.2$ & septo-optic dysplasia & autosomal recessive \\
\hline PROP1 & $5 q$ & short stature, hypothyroid, CPHD & autosomal recessive \\
\hline LHX3 & $9 q 34.3$ & CPHD & autosomal recessive \\
\hline LHX4 & $1 q 25$ & CPHD & autosomal dominant \\
\hline SOX2 & $3 q 26.3-q 27$ & microphthalmia/midline CNS defects, CPHD & autosomal dominant, sporadic \\
\hline SOX3 & $\mathrm{Xq} 26.3$ & midline CNS anomalies, CPHD & $\mathrm{X}$-linked recessive \\
\hline \multicolumn{4}{|c|}{ Putative genes } \\
\hline NELF & $9 q 34.3$ & $\mathrm{IHH} / \mathrm{KS}$ & digenic/monogenic? \\
\hline CHD7 & $8 \mathrm{q} 12.2$ & CHARGE syndrome, KS & autosomal dominant, sporadic \\
\hline PROK2 & $3 \mathrm{p} 21.1$ & KS? & $?$ \\
\hline PROKR2 & $20 \mathrm{p} 13$ & KS? & ? \\
\hline
\end{tabular}

meso/metanephros, and cartilage/limb buds [23]. Some patients with KS may also manifest a variety of nonreproductive abnormalities including renal agenesis and midline facial defects. In some patients, neurologic abnormalities may also be present, such as synkinesia (mirror movements of extremities), cerebellar dysfunction, deafness, eye abnormalities, and mental retardation. A careful search for midfacial and brain defects, along with documenting the presence of two kidneys by ultrasound, has become important in taking care of these patients. The expression patterns of KAL1 correlate closely with the associated anomalies identified in $\mathrm{IHH} / \mathrm{KS}$ patients, thereby providing useful information to clinicians taking care of these patients.

Patients with KS appear to have a defect in migration of $\mathrm{GnRH}$ neurons, although the precise localization of the defect in olfactory and GnRH neuron co-migration is unknown. The function of a nosmin-1 remains unknown, but it is a secreted protein containing a cysteine-rich region, a highly conserved four-disulfide core whey acid protein (WAP) domain, four fibronectin type III (FNIII) repeats, and a C-terminal histidine-rich region $[18,19]$. The WAP domain is common among protease inhibitors, which have been shown to play a role in axonogenesis and neuronal migration. FNIII domains are present in cellular adhesion molecules, extracellular matrix proteins, and protein tyrosine kinases and phosphatases that have been implicated in neuronal migration and in axon targeting $[18,19]$.

Experimental evidence supports these putative functions of anosmin-1. In the mouse, anosmin-1 stimulates axonal branch formation from olfactory bulb output neurons [24]. In C. elegans, the WAP domain influences axon targeting, and the FNIII region appears necessary for axon targeting and axonal branching [25]. Anosmin-1 has been hypothesized to provide a scaffold to direct migration of both olfactory and GnRH neurons to their proper anatomic locations. Disruption of wild-type anosmin-1 protein results in impaired neuronal migration and KS results. Documentation of impaired neuronal mi- 
gration has been reported in the autopsy of one fetus with KS, further supporting this hypothesis [26]. Anosmin-1 has also been shown to directly stimulate GnRH neuron migration of mouse GnRH (GN11) neuronal cells in vitro [27], and knockdown of kal1.1 (not the second gene kal1.2) in zebrafish interferes with $\mathrm{GnRH}$ neuron migration [28].

Mutations in KAL1 account for $33-70 \%$ of familial cases of KS and 3.1-27.8\% of apparently sporadic forms of IHH with anosmia [29]; [18-21, 30-46]. Up to half of males with KAL1 mutations may have unilateral renal agenesis [46]. No KAL1 mutations have been described to date in females although this has not been studied in a large sample. It is clear that some female IHH patients are anosmic or hyposmic, suggesting the involvement of other genes affecting olfactory development and $\mathrm{GnRH}$ function. As is true in human genetic disease, marked phenotypic variability may occur, even within families [33]. Some investigators have suggested that the phenotype of patients with KAL1 mutations is more severe than in those with other causative mutations [34, 42]. Severity was defined by the presence of cryptorchidism, absent $\mathrm{LH}$ pulses, and lack of response to exogenous GnRH [34, 42]. Reported KAL1 mutations described to date and their relation to the protein structure are reviewed elsewhere, and include deletions, missense, and frameshift mutations [18-21, 29-46]. Although three different missense mutations were tested to determine if they affect migration of GnRH neuronal cells (NLT cell), none reduced migration in vitro [27]. This in vitro assay does provide a possible method to test the functional significance of KAL1 mutations.

\section{FGFR1}

The second gene for KS (KAL2 locus) was found to be the FGFR1 gene. The positional cloning of this gene was aided by the identification of two patients with contiguous gene deletion syndromes on chromosome 8p11.2-p12 who also had KS [47]. No additional gene deletions were identified in $43 \mathrm{KS}$ patients, but 12/129 [9\%] had heterozygous FGFR1 point mutations [47]. Subsequent studies of both males and females with autosomal dominant $\mathrm{IHH} / \mathrm{KS}$ have indicated that FGFR1 mutations may cause either anosmic/hyposmic (KS) or normosmic IHH [17, 31, 32, 47-51; 52]. Current data suggest that FGFR1 mutations occur in $10 \%$ of either anosmic or normosmic IHH. Some patients with FGFR1 mutations may also have associated neurologic abnormalities and midfacial defects, similar to those with X-linked KS. As is true in many autosomal dominant diseases, a complicating and chal- lenging feature among families with inactivating FGFR1 mutations is reduced penetrance and variable expressivity $[17,31,32,47-51]$. At least 39 mutations leading to $\mathrm{IHH}$ with or without anosmia have been described to date [17, $31,32,47-51]$. More recently, functional analysis of mutations have demonstrated an impairment of FGF signaling in vitro $[17,51]$.

The human FGFR1 gene is comprised of 18 exons contained within $56 \mathrm{~kb}$ of genomic DNA encoding a single transmembrane receptor consisting of three immunoglobulin-like (Ig) domains, a heparin binding domain, and two tyrosine kinase domains. FGFR1 binds FGF1 and FGF2 with high affinity, involving a K18K sequence essential for receptor activity and interaction with heparin [53]. Since FGFR1 and KAL1 both utilize heparin sulfate proteoglycans, it is possible that anosmin-1 could be a ligand for FGFR1. The importance of the FGF pathway in GnRH neuron development has been demonstrated by a number of studies. FGFR1, along with FGFR2 and FGFR3, is expressed in the nasal placode about E10.5 in the mouse, when GnRH neurons first appear. FGFR1 and FGFR3 are also expressed in GnRH neurons at E15.5 and postnatally in the mouse [54]. Additionally, an attenuation of neurite outgrowth has been described following stable transfection of an Fgfrl dominant negative mutant. These experimental findings indicate that FGF signaling is involved in $\mathrm{GnRH}$ neuron specification, migration, and axonal targeting [54].

It is interesting that human FGFR1 mutations may be activating or inactivating. In fact, the first FGFR1 mutations described were activating mutations that cause craniosynostosis and other skeletal anomalies such as craniofacial-skeletal dysplasia (Jackson-Weiss syndrome), Pfeiffer syndrome, trigonocephaly, osteoglophonic dysplasia, and Antley-Bixler syndrome [55-58]. However, inactivating mutations cause $\mathrm{IHH} / \mathrm{KS}$, but it is interesting that skeletal effects occur in both activating and inactivating mutations of the FGFR1 gene.

\section{GNRHR}

Mutations in the GnRH receptor (GNRHR) gene were initially thought to be the most common cause of normosmic IHH [59-61], but now it appears that the frequency of FGFR1 mutations might be greater [17, 51]. The GNRHR is a G-protein-coupled receptor (GPCR) localized to the cell surface of pituitary gonadotropes, which contains the characteristic seven transmembrane domains and intra- and extracellular loops, but notably lacks an intracellular cytoplasmic tail. When the GnRH ligand reaches the pituitary gonadotropes via the hy- 
pophyseal portal system and binds to the GNRHR, second messenger inositol trisphosphate $\left(\mathrm{IP}_{3}\right)$ is released which then stimulates intracellular calcium release which in turn triggers gonadotropin synthesis and release.

The human GNRHR gene consists of three exons spanning $18.7 \mathrm{~kb}$ of genomic DNA, and was the first gene shown to have mutations in autosomal recessive IHH [59-61]. More than 21 different GNRHR mutations have been described in $\mathrm{IHH}$, most of which are compound heterozygous missense mutations [34, 59-76]. Nearly all human GNRHR mutations occur in exons 1 or 3 , but they are dispersed throughout different domains of the receptor (extracellular, transmembrane, and intracellular) $[34,59-76]$. Two mutations comprise nearly half of the reported alleles, even among different ethnic groups - Gln206Arg mutation [32.6\%] and Arg262Gln (15.2\%) [59]. Just over half of the reported GNRHR mutations interfere with ligand binding, while the remainder affect signal transduction. In addition, some mutations impair gonadotropin subunit and GNRHR promoter activity. Interestingly, studies utilizing site-directed mutagenesis and in vitro analysis have shown that some GNRHR mutations appear to act as dominant negative mutations [77]. The clinical significance of this is unclear, since reported IHH patients have two mutant alleles while heterozygotes do not have any noticeable phenotype.

Findings from several large studies suggest that the prevalence of GNRHR mutations in all IHH patients ranges between 2 and 5\% [59]. To date, there have been no reports of GNRHR mutations in anosmic or hyposmic IHH patients, indicating the prevalence of GNRHR mutations in normosmic IHH patients is between 3.5 and $10.6 \%$ [59]. In IHH families demonstrating clear autosomal-recessive inheritance, the prevalence is estimated to be between 6 and 11\% [59].

In our recent review of GNRHR mutations, about $60 \%$ of the probands had complete IHH (no evidence of sexual development) [59]. The remainder had incomplete $\mathrm{IHH}$, but the phenotype was unknown in several patients. Variable expressivity has also been reported even within the same family, since some affected patients may show some signs of pubertal development while others exhibit a total lack of pubertal development [59]. Endocrinologic findings may also vary for patients with the same mutations. Although successful ovulation and pregnancy with exogenous $\mathrm{GnRH}$ has been reported in patients with this mutation, no live births were achieved $[65,69]$. It is likely that the status of other modifier genes, epistatic events and environmental factors influence the final phenotype of patients with GNRHR mutations.

\section{Other Causes of IHH/KS}

\section{Hypothalamus}

KISS1/GPR54

Although kisspeptins, which are ligands for the GPR54 (G-protein-coupled receptor 54), were originally isolated from melanomas (the first kisspeptin was termed metastin), the significance of this pathway in reproduction did not become apparent until the positional cloning of the GPR54 gene in IHH patients. Independently, two groups studied consanguineous families by linkage analysis and demonstrated very high LOD scores for chromosome 19, where the GPR54 gene resides [78, 79]. In the Saudi Arabian family, DNA sequencing revealed a homozygous missense mutation, while in another unrelated patient, compound heterozygosity for a nonsense mutation (R331X) and a nonstop (X399R) was identified [79]. All three mutations demonstrated impaired signal transduction (diminished inositol phosphate production) in vitro [79]. A French group identified a homozygous missense mutation and a homozygous 155-bp deletion in two different normosmic IHH patients [78]. The missense mutation was later found to also impair GPR54 signaling [80]. No definitive mutations in the KISS1 gene have yet been identified in humans.

Patients with mutations that were studied had impaired GnRH secretion, but had some impaired gonadotropin response to pulsatile GnRH [78, 79]. Affected females respond well to gonadotropin for ovulation induction and achieve normal pregnancy, delivery, postpartum recovery and lactation [81]. As might be expected in an autosomal-recessive disease, heterozygous offspring appear to be normal, with the oldest known child, a 15-yearold girl, having normal puberty and menarche [81]. Further support for the role of GPR54 in normal puberty comes from the knockout mouse, which was hypogonadal. Homozygous knockout mice, however, had a normal anatomic location of $\mathrm{GnRH}$ neurons and normal $\mathrm{GnRH}$ content in the brain, suggesting that GPR54 signaling is important in GnRH release [79]. A variety of additional rare sequence variants of GPR54, some of which are likely to be functional, have been identified, but their consequences are not completely understood [82-85].

Kisspeptins are most highly expressed in the placenta among other tissues, but they are also found in the anteroventral periventricular (AVPV) nucleus and the arcuate nucleus of the hypothalamus. Neurons from these nuclei send projections to the medial preoptic area of the hypothalamus where GnRH neurons reside and secrete GnRH into the hypophyseal portal system. It is known 
that GPR54 is present in $50-75 \%$ of GnRH neurons [ $86-$ 88]. The transition from the prepubertal state to puberty is marked by kisspeptin activation of GPR54 [89]. Kisspeptin infusions result in increased pituitary gonadotropin secretion, an effect that can be abolished by GnRH antagonist administration, indicating a hypothalamic effect of kisspeptin upon GnRH release [89-91]. Gonadectomy increases and sex steroid replacement decreases kisspeptin expression in the arcuate nucleus, whereas the opposite is true in the AVPV nucleus $[92,93]$. These findings suggest that kisspeptin signaling may be important in steroid feedback, and that perhaps the LH surge may be influenced by differential effects of kisspeptin upon these hypothalamic nuclei.

\section{LEP and LEPR}

Leptin is a protein secreted by white adipose tissue that regulates body weight by decreasing food intake and increasing energy expenditure. Leptin is also involved in the modulation of neuroendocrine, reproductive, immune, and cardiovascular systems, particularly in the energy-deficient state. Pulsatile leptin secretion is maximal during the evening and early morning hours [94], and may exert its influence by acting upon KISS1 neurons in the arcuate nucleus [95]. Translational support for the role of leptin in regulating the HPG axis was reported by Welt et al. [96] who found that three of eight women with hypothalamic amenorrhea ovulated following a 3-month leptin infusion. Leptin binds to the leptin receptor (LEPR), a member of the cytokine family of receptors. Leptin signaling involves activation of the STAT3 pathway intracellularly and as well as interaction with the melanocortin 4 receptor (MC4R) to produce anorectic effects [97].

More definitive evidence of leptin's role in reproduction has come from the molecular analysis of individuals with severe, early-onset obesity. Mutations in leptin (LEP) [98-101] or in leptin receptor (LEPR) [102, 103] lead to hyperphagia and morbid obesity in early childhood. The first human LEP gene mutation was characterized in a family with two obese prepubertal children who had extremely low serum leptin levels, but all subjects were prepubertal [98]. Subsequently, a second LEP gene mutation was identified in a consanguineous family containing 3 affected obese individuals [99]. A 14-year-old female presented with primary amenorrhea and a 22 -year-old male had irreversible pubertal delay, low testosterone, low gonadotropins, but a normal response to exogenous hCG and GnRH. Both affected family members were homozygous for a missense LEP gene mutation impairing leptin secretion in vitro [99]. The phenotype of humans with
LEP mutations is similar to leptin-deficient $o b / o b$ mice since they manifest extreme obesity, hyperinsulinemia, and hypogonadotropic hypogonadism, but unlike the mice, the patients do not have hyperglycemia, hypercortisolemia, and stunted height [99]. Only 12 LEP mutations have been identified to date [104] in individuals with extreme, early-onset obesity, so the prevalence in all $\mathrm{IHH} / \mathrm{KS}$ patients is likely to be very low. The presence of LEP mutations should be considered in IHH patients who are extremely obese and have low serum levels of leptin.

Leptin-resistant $d b / d b$ mice have mutations of the Lepr gene, but until recently [104] only one LEPR mutation was described in humans [102]. Leptin resistance was observed in a family of severely obese females with hypogonadotropic hypogonadism and elevated serum levels of leptin. Homozygosity for a LEPR splice mutant resulted in exon-skipping, thereby truncating the receptor so that it lacked both the transmembrane and intracellular domains [102]. In addition to IHH, this patient also had mildly reduced secretion of GH and TSH [102]. Recently, a subset $(n=300)$ of a large cohort of 2,100 early-onset obese subjects with a BMI standard deviation score $=4.5$ who were negative for mutations in known obesity genes were screened for LEPR mutations [104]. Eight of these 300 (2.7\%) subjects had either missense or nonsense LEPR mutations, all of which impaired LEPR signaling in vitro. The affected patients demonstrated, in addition to severe obesity, hyperphagia, altered immune function, and delayed puberty secondary to IHH. Interestingly, serum leptin levels were not different from similarly obese patients without LEPR mutations, and somewhat surprisingly, the clinical features of patients with LEPR mutations were less severe than those with LEP mutations [104].

\section{NROB1}

Another X-linked cause of human IHH/KS is adrenal hypoplasia congenita (AHC)/IHH caused by mutations of the NROB1 gene [105]. This gene was cloned from the dosage sensitive sex reversal (DSS) region of chromosome Xp21 in humans, which when duplicated has been reported to cause undermasculinization in $46, \mathrm{XY}$ males $[105,106]$. The identification of NROB1 gene was aided by the findings from patients with a contiguous gene deletion sequence on Xp21 manifesting Duchenne muscular dystrophy and glycerol kinase deficiency in addition to AHC/IHH. The human NROB1 gene encodes for the DAX1 (DSS- $\underline{A} H C$ critical region of the $\underline{X}$ chromosome, gene 1) protein, which is a member of the steroid hormone receptor superfamily which has no known ligand 
(an orphan receptor). DAX1 is a transcription factor necessary for normal development of the hypothalamus, pituitary gonadotropes, and adrenal cortex $[105,106]$.

Males with NROB1 mutations usually present with adrenal failure in infancy or childhood due to an underdeveloped permanent zone of the adrenal gland [105112]. Children that are adequately treated with adrenal steroids have delayed puberty due to IHH. Occasionally, patients develop adrenal insufficiency later in life or only after targeted testing of the adrenal gland [110-112]. Unfortunately, patients with NROB1 mutations do not respond well to gonadotropins and may show minimal response to pulsatile $\mathrm{GnRH}$, implicating an inherent defect in the gonads $[113,114]$. A large variety of different NROB1 mutations, including deletions and point mutations, have been reported in AHC patients, which have been almost completely confined to males [105-112, 114122]. Of interest though, a homozygous NROB1 mutation was reported in an $\mathrm{IHH}$ female without adrenal failure within a family containing two males with AHC. Her homozygosity was thought to be due to a gene conversion event. Female carriers with DAX1 mutations may manifest delayed puberty [109].

DAX1 appears to regulate gonadotropin secretion at both hypothalamic and pituitary levels $[122,123]$. DAX1 may also inhibit transcription of another important steroid receptor, SF-1, which is expressed in the same tissues and is important in sexual differentiation [123]. Although initial studies suggested that NROB1 might be an ovarian determinant gene because of its localization within the DSS region on Xp, a conditional knockout of the mouse ortholog of NROB1 (Nrob1) did not confirm this [124]. These mice demonstrated normal ovarian development and function; however, male mice displayed degeneration of testicular germinal epithelium independent of gonadotropin and testosterone abnormalities [124]. These findings demonstrated the importance of Nrobl in spermatogenesis more so than in ovarian development.

\section{PCSK1}

We are only aware of a single case of IHH caused by a mutation in the prohormone convertase, subtilisin/kexin type, 1 (PCSK1) gene [125-127]. Another described patient died at 18 months. The affected female presented with extreme early-onset obesity, IHH, hypocortisolism, and abnormal glucose homeostasis. She had elevated plasma proinsulin and pro-opiomelanocortin (POMC) concentrations, and very low insulin levels [125-127]. Compound heterozygous PCSK1 mutations were demonstrated to have functional effects in vitro. The frame- shift mutation predicted protein truncation, and the missense mutation prevented processing and lead to retention in the endoplasmic reticulum [125-127]. Because of the similarity of this proband to the fat/fat mouse, it appears that molecular defects in prohormone conversion may constitute a mechanism for obesity and endocrine disease common to humans and rodents.

\section{Pituitary Genes \\ HESX1}

A variety of genes involved in gonadotropin secretion and function may cause hypogonadotropic hypogonadism; however, they will only be briefly discussed here. HESX1 is a transcription factor and member of the paired-like homeobox genes, which contains repression domains thought to cause repression of transcription of target genes. The mouse ortholog, Hesx 1, is expressed in the early forebrain, but later in development its expression is restricted to Rathke's pouch, which becomes the anterior pituitary gland [128]. Humans with either heterozygous (autosomal dominant) or homozygous (autosomal-recessive) HESX1 mutations may have septo-optic dysplasia (agenesis of corpus callosum, panhypopituitarism, and hypoplastic optic nerves) [128-135]. However, HESX1 mutations only account for a small percentage of those with SOD. Other HESX1 mutations have been found in isolated growth hormone deficiency [128-135]. HESX1 mutations may interfere with DNA binding [128] or the repression of target genes such as PROP1 [133, 134].

\section{PROP1}

Like HESX1, PROP1 is also a member of the pairedlike homeobox genes. In contrast to HESX1 though, PROP1 is thought to be both a transcriptional activator and repressor. PROP1 mutations cause autosomal recessive combined pituitary hormone deficiency (CPHD), indicating its importance in anterior pituitary gland development. These patients may have deficiencies of GH, TSH, prolactin, gonadotropins, and ACTH $[132,135-$ 140]. They typically demonstrate extreme short stature because of deficiencies of both GH and TSH. Although there have been many different PROP1 mutations, the most common is a 2-bp frameshift deletion [132, 135140]. No causative PROP1 mutations were identified in 175 unrelated IHH/KS patients who did not manifest deficiencies of other pituitary hormones [140]. Mutations of mouse Propl cause the Ames dwarf mouse, which has a similar phenotype to that of humans [141]. 


\section{SOX 2 and SOX 3}

Mutations in these two HMG box transcription factors have been found in humans with hypogonadotropic hypogonadism. Heterozygous de novo SOX 2 mutations have been identified in patients with bilateral anophthal$\mathrm{mia} /$ microphthalmia, developmental delay, short stature, and male genital tract abnormalities. Recently, mice heterozygous for a targeted Sox 2 disruption did not manifest these eye defects, but demonstrated abnormal anterior pituitary development with GH, TSH, and LH deficiency [142]. Eight of 235 (3.4\%) patients with 'congenital hypothalamic-pituitary disorders' were found to have heterozygous SOX2 sequence variations, most of which were de novo [142]. Some mutations were nonsense or frameshift deletions or insertion, while others were missense mutations that were shown to impair function - either DNA binding, nuclear translocation, or transactivation. $\mathrm{Pa}$ tients with SOX2 mutations had eye defects, along with anterior pituitary hypofunction including IHH. However, there were also additional defects of the corpus callosum, hypothalamic hamartomas, sensorineural hearing loss, and esophageal atresia [142]. These findings in both mouse and human suggest that SOX2 is necessary for the normal development and function of the HPG axis.

Mutations in SOX3 cause an X-linked recessive form of pituitary deficiency. Several SOX3 mutations were reported, the first an in-frame 33-bp duplication in a family with X-linked mental retardation, facial abnormalities, and GH deficiency [143]. Another 686-kb duplication was identified in two siblings with variable degrees of hypopituitarism, corpus callosal abnormalities, anterior pituitary hypoplasia, an ectopic posterior pituitary, and an absent infundibulum [144]. Mental retardation was not present in these siblings. Corroborative findings have been identified in mice with targeted deletion of SOX3. The phenotype was that of impaired pituitary development and midline structures [145]. These pituitary and hypothalamic defects persisted postnatally.

\section{LHX3 and LHX4}

Both LHX3 and LHX4 are homeobox genes, which are transcription factors involved in anterior pituitary development. The LHX3 protein has two LIM motifs at the amino-terminus and a DNA-binding region in the carboxy-terminus. LHX3 mutations cause autosomal-recessive CPHD, while LHX4 mutations cause an autosomaldominant form $[132,146,147]$. The phenotype of patients with LHX3 gene mutations consists of severe growth retardation (TSH and GH deficiency) and hypogonadotropic hypogonadism $[132,146,147]$. All pituitary hor- mones (TSH, GH, prolactin, FSH, and LH) except ACTH are deficient. Of interest, severe restriction of cervical spine rotation with elevation and anteversion of the shoulders occurs in these patients, which is similar to what is seen with mouse Lhx3 disruption. Although a family with GH, TSH, and ACTH deficiency due to a heterozygous mutation in the LHX4 gene has been described, the child was prepubertal, so gonadotropin levels were not investigated [148]. Recently, a second child was reported with a heterozygous LHX4 missense mutation [149]. Theoretically, LHX4 should also cause hypogonadotropic hypogonadism, but no pubertal aged children have yet been described.

\section{Gonadotropin Genes (LHB and FSH)}

Dimeric pituitary glycoprotein hormones consist of a common $\alpha$-subunit encoded by the chorionic gonadotropin-alpha (CGA) gene and a specific $\beta$-subunit (TSH, hCG, FSH, and LH) encoded by the corresponding gene. Human CGA mutations have yet to be described, but hypothyroidism and hypogonadotropic hypogonadism would be expected. The human LHB/HCGB gene complex consists of a single LHB gene and six HCGB genes, which are highly polymorphic [150]. Several LHB mutations have now been identified. The extended phenotype, however, can be very variable and cause either hypergonadotropic or hypogonadotropic hypogonadism [151, 152]. The first LHB mutation (a homozygous missense mutation) was found in a male with delayed puberty, small testes, oligospermia, and low serum testosterone with elevated immunoreactive, but reduced biologically active LH levels [151]. If the mutation results in inability of the LH molecule to be processed and secreted, isolated LH deficiency will be present. In another male with a different missense mutation, $\mathrm{LH}$ was unable to be processed and secreted, so the phenotype was isolated LH deficiency [152]. This patient had a eunuchoid habitus, gynecomastia, small $(8 \mathrm{ml})$ testes, undetectable $\mathrm{LH}$, and elevated FSH $(23 \mathrm{mIU} / \mathrm{ml})$. Injections of hCG for a year increased testicular volume to $14 \mathrm{ml}$ but improved sperm count only to $1,000 / \mathrm{ml}$. Recently the first female with an LHB mutation was reported, and as predicted puberty was normal, but she was amenorrheic with infertility. The mutation was a homozygous splice mutant that was seen in this female and two affected males from their consanguineous family [153].

FSHB gene mutations have been identified in autosomal recessive isolated FSH deficiency in several females [154-156] and males [155, 157-159]. All mutations (missense, nonsense, or 2-bp deletion) in females have been 
found in exon 3, all of which result in low immunoreactive and bioactive FSH levels probably by impairing dimer formation and secretion. Most females completely lack breast development and present with primary amenorrhea [154-156]. Estradiol levels are low (menopausal); FSH is undetectable or very low; and LH levels are elevated in females (LH may be normal to mildly elevated in males).

Although females with isolated FSH deficiency have elevated serum LH levels, they do not have hirsutism or hyperandrogenemia $[154,160,161]$. Since isolated FSH deficiency is associated with low androgens, this suggests that FSH plays an important role in ovarian androgen production, perhaps by inducing the androgen-dependent enzyme 17-hydroxylase activity, inhibin, growth factors, or increasing LH receptors [154, 160, 161].

\section{New IHH/KS Candidate Genes}

\section{CHD7}

Mutations in the human chromodomain helicase DNA-binding protein 7 (CHD7) gene have been shown to cause CHARGE syndrome, an autosomal-dominant or sporadic disorder consisting of coloboma of the eye, heart defects, choanal atresia, retardation of growth and development, genito-urinary anomalies, ear abnormalities (vestibular and auditory) [162]. This gene was initially identified using array comparative genomic hybridization (CGH) to identify a $2.3-\mathrm{Mb}$ de novo microdeletion on chromosome 8q12 in 2 patients with CHARGE syndrome. One of these patients had an apparently balanced translocation reported previously [163]. All nine genes within the region were sequenced in 17 CHARGE syndrome patients without deletions, and 10 heterozygous CHD7 mutations ( 7 nonsense, 2 missense, and 1 potential splice mutant) were identified [162]. Of interest, CHD7 mutations occur in $60-80 \%$ of patients with CHARGE syndrome and span across the gene, but there currently appears to be no correlation between genotype and phenotype and most are de novo [162, 164-166]. Available data indicates that $\mathrm{CHD} 7$ appears to play an important role in the nucleus in binding to chromatin and regulating gene expression $[162,167]$.

Mutations in the mouse Chd7 gene have been identified by ENU mutagenesis techniques in mice. Multiple alleles associated with vestibular disturbances (head bobbling and circling behavior) due to abnormal lateral semicircular canals clustered together on mouse chromosome 4 [168]. Upon DNA sequencing of the mouse Chd7 gene, 9 heterozygous mutants were identified ( 6 nonsense and 3 splice mutants) confirming that Chd7 was involved in the mouse phenotype, similar to humans with CHARGE syndrome. Defects in these heterozygous mice included cleft palate, choanal atresia, cardiac septal defects, hemorrhage, prenatal death, vulvar and clitoral defects, and keratoconjuncitivis sicca [168].

Chd7 is expressed ubiquitously (by semiquantitative RT-PCR) in fetal and adult tissue, including the olfactory epithelium, eye, inner ear, and vascular system [162]. However, at E10.5 in the mouse, Chd7 is selectively expressed in the forebrain, olfactory pit, optic vesicle, hindbrain, cardiac outflow tract, facio-acoustic preganglion, and mandibular portion of the first branchial arch [164]. In addition, loss of function in gene-trapped reporter mice resulted in embryonic lethality at E10.5 [169], which suggests that homozygous mutations might also be lethal. Chd7 expression in this useful animal model was localized to the brain, retina, ear, craniofacial structures, pituitary, heart, and kidney at the expected time of endogenous Chd7 mRNA expression (E10.5) [169].

Several studies implicate the CHD7 gene in $\mathrm{IHH} / \mathrm{KS}$, although the patients described have not been fully characterized. In a study of 14 children with CHARGE syndrome aged 6-18 years, all were found to be anosmic or hyposmic compared with controls [170]. In another study of CHARGE syndrome children, 19/20 affected boys had micropenis and/or cryptorchidism suggestive of IHH, although all were prepubertal [171]. Seven of 9 neonatal boys had low serum testosterone levels during the window period ( $<6$ months of age) when testicular function can be determined. None of 7 females $>12$ years began puberty spontaneously and 5/7 had a subnormal FSH and $\mathrm{LH}$ responses to GnRH stimulation. Ten CHARGE syndrome patients had anosmia when tested by a smell test and all 18 having an MRI had abnormal olfactory bulbs. These findings are not conclusive, but nevertheless suggest that some patients with CHARGE syndrome could have an IHH/KS phenotype [171]. In fact, recently a female affected with CHARGE syndrome due to a CHD7 mutation had a KS-like phenotype [172]. These findings indicated that perhaps $\mathrm{IHH} / \mathrm{KS}$ could be a milder allelic variant of CHARGE syndrome, which warrants further study.

\section{NELF}

Nasal embryonic LHRH factor (NELF) was cloned and characterized from migrating GnRH neurons using differential screening techniques [173]. A knockout mouse has not yet been published at the time of this writing. High levels of mRNA and protein expression were 
found in the forebrain, olfactory epithelium, and olfactory pit of embryos with maximal expression between E12.5 and E14.5 in the olfactory epithelium and olfactory pit [173]. NELF protein expression was demonstrated in the cell soma and processes and appeared to be on the surface of the neurons. Since NELF is present on both olfactory and GnRH neurons, these authors suggested that NELF may serve as a common guidance cue for olfactory axon projections and subsequent migration of $\mathrm{GnRH}$ neurons [173].

When nasal explants were treated with antisense oligonucleotides, NELF protein decreased by $60 \%$, GnRH neuron fiber complexity and length decreased, and there was a reduction in the number of GnRH neurons in the periphery of the explant. These findings suggested that NELF may play an important role in GnRH neuron migration, puberty, and reproduction. The human ortholog was cloned by Miura et al. [174] and, although they identified one heterozygous missense mutation, no functional analysis was performed [174]. Recently, the coexistence of a NELF mutation and an FGFR1 mutation was reported, which together produced IHH [175]. These findings in mice and humans indicate that NELF certainly has the potential to be an important candidate gene for IHH/ KS.

\section{PROK2 and PROKR2}

Since mice lacking the prokineticin receptor (Prokr2) demonstrate impaired development of the olfactory bulbs and deficient GnRH neurons [176], genes for the both the ligand prokineticin 2 (PROK2) and its receptor (PROKR2) have been studied in patients with IHH [177]. Although putative mutations were identified in both the ligand and the G-protein-coupled receptor, the functional significance of these genes in $\mathrm{IHH} / \mathrm{KS}$ awaits confirmation by additional studies.

\section{Conclusions}

$\mathrm{GnRH}$ and olfactory neurons migrate from the olfactory placode region into the brain. $\mathrm{GnRH}$ neurons, along with a branch of the vomeronasal nerve, finally reside in the hypothalamus, where they secrete pulsatile GnRH which controls the neuroendocrine functions of reproduction. Impairment of both $\mathrm{GnRH}$ and olfactory neuron migration results in KS, the combination of $\mathrm{IHH}$ and anosmia, while some patients exhibit normosmic IHH. Although long thought to be an irreversible process, it now appears that LH pulsatility may be restored in some patients when treatment is discontinued. Mutations in the KAL1 and FGFR1 genes constitute the only known molecular etiology for patients with KS, but FGFR1 mutations also result in normosmic IHH.

Mutations in a variety of other genes also occur in normosmic IHH, most notably the GNRHR. Although not as common, the GPR54 and LEP/LEPR genes play significant physiologic roles in normal puberty. A number of pituitary genes also possess mutations in patients with pituitary deficiency that includes hypogonadotropic hypogonadism. Finally, several new genes - CHD7, NELF, PROK2, and PROKR2 - make excellent candidate genes for $\mathrm{IHH} / \mathrm{KS}$ since they are expressed in $\mathrm{GnRH}$ and olfactory neurons. Digenic disease has recently been reported, and it will be interesting to further dissect the molecular basis of disorders of puberty and reproduction. Candidate gene screening and positional cloning utilizing balanced chromosomal rearrangements or affected consanguineous families will reveal additional important genes involved in the pathogenesis of IHH/KS.

\section{Acknowledgements}

L.C.L. has been supported by NIH grants HD33004 and HD040287. We would like to acknowledge Lynn Chorich for her efforts in supervising and running our laboratory.

\section{References}

1 Wierman ME, Pawlowski JE, Allen MP, Xu M, Linseman DA, Nielsen-Preiss S: Molecular mechanisms of gonadotropin-releasing hormone neuronal migration. Trends Endocrinol Metab 2004;15:96-102.

-2 Schwarting GA, Kostek C, Bless EP, Ahmad $\mathrm{N}$, Tobet SA: Deleted in colorectal cancer (DCC) regulates the migration of luteinizing hormone-releasing hormone neurons to the basal forebrain. J Neurosci 2001;21:911-919.
-3 Schwarting GA, Raitcheva D, Bless EP, Ackerman SL, Tobet S: Netrin 1-mediated chemoattraction regulates the migratory pathway of LHRH neurons. Eur J Neurosci 2004;19:11-20.

-4 Mellon PL, Windle JJ, Goldsmith PC, Padula CA, Roberts JL, Weiner RI: Immortalization of hypothalamic GnRH neurons by genetically targeted tumorigenesis. Neuron 1990; 5:1-10.
5 Radovick S, Wray S, Lee E, et al: Migratory arrest of gonadotropin-releasing hormone neurons in transgenic mice. Proc Natl Acad Sci USA 1991;88:3402-3406.

6 Grumbach MM: A window of opportunity: the diagnosis of gonadotropin deficiency in the male infant. J Clin Endocrinol Metab 2005;90:3122-3127. 
7 Layman LC, Reindollar RH: The diagnosis and treatment of pubertal disorders. Adolesc Med 1994;5:37-55.

$\checkmark 8$ Reindollar RH, Byrd JR, McDonough PG: Delayed sexual development: study of 252 patients. Am J Obstet Gynecol 1981;140:371380

9 Crowley WF Jr, Filicori M, Spratt DI, Santoro NF: The physiology of gonadotropin-releasing hormone $(\mathrm{GnRH})$ secretion in men and women. Recent Prog Horm Res 1985;41:473531.

-10 Burris AS, Rodbard HW, Winters SJ, Sherins RJ: Gonadotropin therapy in men with isolated hypogonadotropic hypogonadism: the response to human chorionic gonadotropin is predicted by initial testicular size. J Clin Endocrinol Metab 1988;66:1144-1151.

$\checkmark 11$ Layman LC: Hypogonadotropic hypogonadism. Endocrinol Metab Clin N Am 2007;36: 283-296.

-12 Raivio T, Falardeau J, Dwyer A, et al: Reversal of idiopathic hypogonadotropic hypogonadism. N Engl J Med 2007;357:863-873.

$>13$ Waldstreicher J, Seminara SB, Jameson JL, et al: The genetic and clinical heterogeneity of gonadotropin-releasing hormone deficiency in the human. J Clin Endocrinol Metab 1996; 81:4388-4395.

-14 Quinton R, Duke VM, Robertson A, et al: Idiopathic gonadotrophin deficiency: genetic questions addressed through phenotypic characterization. Clin Endocrinol (Oxf) 2001;55:163-174.

-15 Bhagavath B, Podolsky RH, Ozata M, et al: Clinical and molecular characterization of a large sample of patients with hypogonadotropic hypogonadism. Fertil Steril 2006;85: 706-713.

16 Bhagavath B, Layman LC: The genetics of hypogonadotropic hypogonadism. Semin Reprod Med 2007;25:272-286.

-17 Pitteloud N, Acierno JS Jr, Meysing A, et al: Mutations in fibroblast growth factor receptor 1 cause both Kallmann syndrome and normosmic idiopathic hypogonadotropic hypogonadism. Proc Natl Acad Sci USA 2006;103:6281-6286

18 Franco B, Guioli S, Pragliola A, et al: A gene deleted in Kallmann's syndrome shares homology with neural cell adhesion and axonal path-finding molecules. Nature 1991;353: 529-536.

19 Legouis R, Hardelin JP, Levilliers J, et al: The candidate gene for the X-linked Kallmann syndrome encodes a protein related to adhesion molecules. Cell 1991;67:423-435.

-20 Bick D, Franco B, Sherins RS, et al: Intragenic deletion of the KALIG-1 gene in Kallmann's syndrome. N Engl J Med 1992;326: 1752-1755.

-21 Hardelin JP, Levilliers J, Blanchard S, et al: Heterogeneity in the mutations responsible for X chromosome-linked Kallmann syndrome. Hum Mol Genet 1993;2:373-377.
-22 MacColl G, Quinton R, Bouloux PM: GnRH neuronal development: insights into hypogonadotrophic hypogonadism. Trends Endocrinol Metab 2002;13:112-118.

23 Lutz B, Karatani S, Rugarli EI, et al: Expression of the Kallmann syndrome gene in human fetal brain and in the manipulated chick embryo. Hum Mol Genet 1994;3:1717-1723.

24 Soussi-Yanicostas N, de Castro F, Julliard AK, Perfettini I, Chedotal A, Petit C: Anosmin-1, defective in the X-linked form of Kallmann syndrome, promotes axonal branch formation from olfactory bulb output neurons. Cell 2002;109:217-228.

25 MacColl G, Bouloux P, Quinton R: Kallmann syndrome: adhesion, afferents, and anosmia. Neuron 2002;34:675-678.

26 Schwanzel-Fukuda M, Crossin KL, Pfaff DW, Bouloux PM, Hardelin JP, Petit C: migration of luteinizing hormone-releasing hormone (LHRH) neurons in early human embryos. J Comp Neurol 1996;366:547-557.

-27 Cariboni A, Pimpinelli F, Colamarino S, et al: The product of X-linked Kallmann's syndrome gene (KAL1) affects the migratory activity of gonadotropin-releasing hormone (GnRH)-producing neurons. Hum Mol Genet 2004;13:2781-2791.

28 Whitlock KE, Illing N, Brideau NJ, Smith KM, Twomey S: Development of GnRH cells: Setting the stage for puberty. Mol Cell Endocrinol 2006;254-255:39-50.

29 Bhagavath $\mathrm{B}, \mathrm{Xu} \mathrm{N}$, Ozata M, et al: KAL1 mutations are not a common cause of idiopathic hypogonadotrophic hypogonadism in humans. Mol Hum Reprod 2007;13:2530

30 Loidi L, Castro-Feijoo L, Barreiro J, et al: Kallmann's syndrome with a novel missense mutation in the KAL1 gene that modifies the major cell adhesion site of the anosmin-1 protein. J Pediatr Endocrinol Metab 2005; 18: 545-548.

31 Albuisson J, Pecheux C, Carel JC, et al: Kallmann syndrome: 14 novel mutations in KAL1 and FGFR1 (KAL2). Hum Mutat 2005; 25:98-99.

32 Sato N, Katsumata N, Kagami M, et al: Clinical assessment and mutation analysis of Kallmann syndrome 1 (KAL1) and fibroblast growth factor receptor 1 (FGFR1, or KAL2) in five families and 18 sporadic patients. J Clin Endocrinol Metab 2004;89: 1079-1088.

33 Massin N, Pecheux C, Eloit C, et al: X chromosome-linked Kallmann syndrome: clinical heterogeneity in three siblings carrying an intragenic deletion of the KAL-1 gene. J Clin Endocrinol Metab 2003;88:2003-2008.

34 Beranova M, Oliveira LM, Bedecarrats GY, et al: Prevalence, phenotypic spectrum, and modes of inheritance of gonadotropin-releasing hormone receptor mutations in idiopathic hypogonadotropic hypogonadism. J Clin Endocrinol Metab 2001;86:1580-1588.
35 Izumi Y, Tatsumi K, Okamoto S, et al: Analysis of the KAL1 gene in 19 Japanese patients with Kallmann syndrome. Endocr J 2001;48: 143-149.

-36 Jansen C, Hendriks-Stegeman BI, Jansen M: A novel nonsense mutation of the KAL gene in two brothers with Kallmann syndrome. Horm Res 2000;53:207-212.

37 Matsuo T, Okamoto S, Izumi Y, et al: A novel mutation of the KAL1 gene in monozygotic twins with Kallmann syndrome. Eur J Endocrinol 2000;143:783-787.

38 Hou JW, Tsai WY, Wang TR: Detection of KAL-1 gene deletion with fluorescence in situ hybridization. J Formos Med Assoc 1999;98:448-451.

39 Izumi Y, Tatsumi K, Okamoto S, et al: A novel mutation of the KAL1 gene in Kallmann syndrome. Endocr J 1999;46:651-658.

40 O’Neill MJ, Tridjaja B, Smith MJ, Bell KM, Warne GL, Sinclair AH: Familial Kallmann syndrome: a novel splice acceptor mutation in the KAL gene. Hum Mutat 1998;11:340342 .

$41 \mathrm{Gu}$ WX, Colquhoun-Kerr JS, Kopp P, Bode $\mathrm{HH}$, Jameson JL: A novel amino-terminal mutation in the KAL-1 gene in a large pedigree with X-linked Kallmann syndrome. Mol Genet Metab 1998;65:59-61.

42 Georgopoulos NA, Pralong FP, Seidman CE, Seidman JG, Crowley WF Jr, Vallejo M: Genetic heterogeneity evidenced by low incidence of KAL-1 gene mutations in sporadic cases of gonadotropin-releasing hormone deficiency. J Clin Endocrinol Metab 1997;82: 213-217.

43 Hardelin JP, Petit C: A molecular approach to the pathophysiology of the $\mathrm{X}$ chromosome-linked Kallmann's syndrome. Baillières Clin Endocrinol Metab 1995;9:489507.

44 Parenti G, Rizzolo MG, Ghezzi M, et al: Variable penetrance of hypogonadism in a sibship with Kallmann syndrome due to a deletion of the KAL gene. Am J Med Genet 1995; 57:476-478.

$>45$ Hardelin JP, Levilliers J, Young J, et al: Xp22.3 deletions in isolated familial Kallmann's syndrome. J Clin Endocrinol Metab 1993;76:827-831.

46 Hardelin JP, Levilliers J, del Castillo I, et al: X chromosome-linked Kallmann syndrome: stop mutations validate the candidate gene. Proc Natl Acad Sci USA 1992;89:81908194.

47 Dode C, Levilliers J, Dupont JM, et al: Lossof-function mutations in FGFR1 cause autosomal dominant Kallmann syndrome. Nat Genet 2003;33:463-465.

48 Pitteloud N, Acierno JS Jr, Meysing AU, Dwyer AA, Hayes FJ, Crowley WF Jr: Reversible kallmann syndrome, delayed puberty, and isolated anosmia occurring in a single family with a mutation in the fibroblast growth factor receptor 1 gene. J Clin Endocrinol Metab 2005;90:1317-1322. 
-49 Sato N, Hasegawa T, Hori N, Fukami M, Yoshimura Y, Ogata T: Gonadotrophin therapy in Kallmann syndrome caused by heterozygous mutations of the gene for fibroblast growth factor receptor 1: report of three families. Case report. Hum Reprod 2005;20: 2173-2178.

- 50 Sato N, Ohyama K, Fukami M, Okada M, Ogata T: Kallmann syndrome: somatic and germline mutations of the fibroblast growth factor receptor 1 gene in a mother and the son. J Clin Endocrinol Metab 2006;91:14151418.

51 Pitteloud N, Meysing A, Quinton R, et al: Mutations in fibroblast growth factor receptor 1 cause Kallmann syndrome with a wide spectrum of reproductive phenotypes. Mol Cell Endocrinol 2006;254-255:60-69.

- 52 Xu N, Qin Y, Reindollar RH, Tho SP, McDonough PG, Layman LC: A mutation in the fibroblast growth factor receptor 1 gene causes fully penetrant normosmic isolated hypogonadotropic hypogonadism. J Clin Endocrinol Metab 2007;92:1155-1158.

-53 Gill JC, Moenter SM, Tsai PS: Developmental regulation of gonadotropin-releasing hormone neurons by fibroblast growth factor signaling. Endocrinology 2004;145:38303839.

- 54 Tsai PS, Moenter SM, Postigo HR, et al: Targeted expression of a dominant-negative fibroblast growth factor (FGF) receptor in gonadotropin-releasing hormone $(\mathrm{GnRH})$ neurons reduces FGF responsiveness and the size of GnRH neuronal population. Mol Endocrinol 2005; 19:225-236.

-55 White KE, Cabral JM, Davis SI, et al: Mutations that cause osteoglophonic dysplasia define novel roles for FGFR1 in bone elongation. Am J Hum Genet 2005;76:361-367.

56 Hurley ME, White MJ, Green AJ, Kelleher J: Antley-Bixler syndrome with radioulnar synostosis. Pediatr Radiol 2004;34:148-151.

- 57 Kress W, Petersen B, Collmann H, Grimm T: An unusual FGFR1 mutation (fibroblast growth factor receptor 1 mutation) in a girl with non-syndromic trigonocephaly. Cytogenet Cell Genet 2000;91:138-140.

58 Muenke M, Schell U, Hehr A, et al: A common mutation in the fibroblast growth factor receptor 1 gene in Pfeiffer syndrome. Nat Genet 1994;8:269-274.

59 Bhagavath B, Ozata M, Ozdemir IC, et al: The prevalence of gonadotropin-releasing hormone receptor mutations in a large cohort of patients with hypogonadotropic hypogonadism. Fertil Steril 2005;84:951-957.

-60 Layman LC, Cohen DP, Jin M, et al: Mutations in the gonadotropin-releasing hormone receptor gene cause hypogonadotropic hypogonadism. Nat Genet 1998;18:14-15.

-61 de Roux N, Young J, Misrahi M, et al: A family with hypogonadotropic hypogonadism and mutations in the gonadotropin-releasing hormone receptor. N Engl J Med 1997; 337:1597-1602.
62 de Roux N, Young J, Brailly-Tabard S, Misrahi $\mathrm{M}$, Milgrom E, Chaison G: The same molecular defects of the gonadotropin-releasing hormone determine a variable degree of hypogonadism in affected kindred. J Clin Endocrinol Metab 1999;84:567-572.

63 Pralong FP, Gomez F, Castillo E, et al: Complete hypogonadotropic hypogonadism associated with a novel inactivating mutation of the gonadotropin-releasing hormone receptor. J Clin Endocrinol Metab 1999;84: 3811-3816.

64 Kottler ML, Chauvin S, Lahlou N, et al: A new compound heterozygous mutation of the gonadotropin-releasing hormone receptor (L314X, Q106R) in a woman with complete hypogonadotropic hypogonadism: chronic estrogen administration amplifies the gonadotropin defect. J Clin Endocrinol Metab 2000;85:3002-3008.

- 65 Seminara SB, Beranova M, Oliveira LM, Martin KA, Crowley WF Jr, Hall JE: Successful use of pulsatile gonadotropin-releasing hormone $(\mathrm{GnRH})$ for ovulation induction and pregnancy in a patient with GnRH receptor mutations. J Clin Endocrinol Metab 2000;85:556-562.

66 Layman LC, McDonough PG, Cohen DP, Maddox M, Tho SP, Reindollar RH: Familial gonadotropin-releasing hormone resistance and hypogonadotropic hypogonadism in a family with multiple affected individuals. Fertil Steril 2001;75:1148-1155.

67 Costa EM, Bedecarrats GY, Mendonca BB, Arnhold IJ, Kaiser UB, Latronico AC: Two novel mutations in the gonadotropin-releasing hormone receptor gene in Brazilian patients with hypogonadotropic hypogonadism and normal olfaction. J Clin Endocrinol Metab 2001;86:2680-2686.

68 Layman LC, Cohen DP, Xie J, Smith GD: Clinical phenotype and infertility treatment in a male with hypogonadotropic hypogonadism due to mutations Ala129Asp/Arg$262 \mathrm{Gln}$ of the gonadotropin-releasing hormone receptor. Fertil Steril 2002;78:13171320.

-69 Dewailly D, Boucher A, Decanter C, Lagarde JP, Counis R, Kottler ML: Spontaneous pregnancy in a patient who was homozygous for the Q106R mutation in the gonadotropin-releasing hormone receptor gene. Fertil Steril 2002;77:1288-1291.

70 Maya-Nunez G, Janovick JA, Ulloa-Aguirre A, Soderlund D, Conn PM, Mendez JP: Molecular basis of hypogonadotropic hypogonadism: restoration of mutant $(\mathrm{E}(90) \mathrm{K})$ $\mathrm{GnRH}$ receptor function by a deletion at a distant site. J Clin Endocrinol Metab 2002; 87:2144-2149.

71 Silveira LF, Stewart PM, Thomas M, Clark DA, Bouloux PM, MacColl GS: Novel homozygous splice acceptor site $\mathrm{GnRH}$ receptor (GnRHR) mutation: human GnRHR 'knockout'. J Clin Endocrinol Metab 2002;87:29732977.
72 Bedecarrats GY, Linher KD, Janovick JA, et al: Four naturally occurring mutations in the human GnRH receptor affect ligand binding and receptor function. Mol Cell Endocrinol 2003;205:51-64.

73 Wolczynski S, Laudanski P, Jarzabek K, Mittre H, Lagarde JP, Kottler ML: A case of complete hypogonadotropic hypogonadism with a mutation in the gonadotropin-releasing hormone receptor gene. Fertil Steril 2003;79: 442-444.

74 Bedecarrats GY, Linher KD, Kaiser UB: Two common naturally occurring mutations in the human gonadotropin-releasing hormone $(\mathrm{GnRH})$ receptor have differential effects on gonadotropin gene expression and on GnRH-mediated signal transduction. J Clin Endocrinol Metab 2003;88:834-843.

$\checkmark 75$ Karges B, Karges W, Mine M, et al: Mutation Ala(171)Thr stabilizes the gonadotropin-releasing hormone receptor in its inactive conformation, causing familial hypogonadotropic hypogonadism. J Clin Endocrinol Metab 2003;88:1873-1879.

76 Meysing AU, Kanasaki H, Bedecarrats GY, et al: GNRHR mutations in a woman with idiopathic hypogonadotropic hypogonadism highlight the differential sensitivity of luteinizing hormone and follicle-stimulating hormone to gonadotropin-releasing hormone. J Clin Endocrinol Metab 2004;89: 3189-3198

77 Brothers SP, Cornea A, Janovick JA, Conn PM: Human loss-of-function gonadotropinreleasing hormone receptor mutants retain wild-type receptors in the endoplasmic reticulum: molecular basis of the dominantnegative effect. Mol Endocrinol 2004;18: 1787-1797.

-78 de Roux N, Genin E, Carel JC, Matsuda F, Chaussain JL, Milgrom E: Hypogonadotropic hypogonadism due to loss of function of the KiSS1-derived peptide receptor GPR54. Proc Natl Acad Sci USA 2003;100: 10972-10976.

-79 Seminara SB, Messager S, Chatzidaki EE, et al: The GPR54 gene as a regulator of puberty. N Engl J Med 2003;349:1614-1627.

80 Tenenbaum-Rakover Y, Commenges-Ducos M, Iovane A, Aumas C, Admoni O, de Roux $\mathrm{N}$ : Neuroendocrine phenotype analysis in five patients with isolated hypogonadotropic hypogonadism due to a L102P inactivating mutation of GPR54. J Clin Endocrinol Metab 2007;92:1137-1144.

81 Pallais JC, Bo-Abbas Y, Pitteloud N, Crowley WF Jr, Seminara SB: Neuroendocrine, gonadal, placental, and obstetric phenotypes in patients with IHH and mutations in the Gprotein coupled receptor, GPR54. Mol Cell Endocrinol 2006;254-255:70-77.

- 82 Lanfranco F, Gromoll J, von Eckardstein S, Herding EM, Nieschlag E, Simoni M: Role of sequence variations of the GnRH receptor and $\mathrm{G}$ protein-coupled receptor 54 gene in male idiopathic hypogonadotropic hypogonadism. Eur J Endocrinol 2005;153:845-852. 
$>83$ Semple RK, Achermann JC, Ellery J, et al: Two novel missense mutations in G proteincoupled receptor 54 in a patient with hypogonadotropic hypogonadism. J Clin Endocrinol Metab 2005;90:1849-1855.

84 Cerrato F, Shagoury J, Kralickova M, et al: Coding sequence analysis of GNRHR and GPR54 in patients with congenital and adultonset forms of hypogonadotropic hypogonadism. Eur J Endocrinol 2006;155(suppl 1): S3-S10.

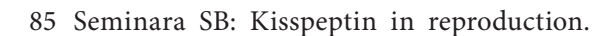
Semin Reprod Med 2007;25:337-343.

-86 Messager S, Chatzidaki EE, Ma D, et al: Kisspeptin directly stimulates gonadotropin-releasing hormone release via $\mathrm{G}$ proteincoupled receptor 54. Proc Natl Acad Sci USA 2005;102:1761-1766.

87 Parhar IS, Ogawa S, Sakuma Y: Laser-captured single digoxigenin-labeled neurons of gonadotropin-releasing hormone types reveal a novel $G$ protein-coupled receptor (Gpr54) during maturation in cichlid fish. Endocrinology 2004;145:3613-3618.

88 Irwig MS, Fraley GS, Smith JT, et al: Kisspeptin activation of gonadotropin releasing hormone neurons and regulation of KiSS-1 mRNA in the male rat. Neuroendocrinology 2004;80:264-272.

89 Plant TM, Ramaswamy S, Dipietro MJ: Repetitive activation of hypothalamic G protein-coupled receptor 54 with intravenous pulses of kisspeptin in the juvenile monkey (Macaca mulatta) elicits a sustained train of gonadotropin-releasing hormone discharges. Endocrinology 2006;147:1007-1013.

90 Matsui H, Takatsu Y, Kumano S, Matsumoto $\mathrm{H}$, Ohtaki T: Peripheral administration of metastin induces marked gonadotropin release and ovulation in the rat. Biochem Biophys Res Commun 2004;320:383-388.

-91 Dhillo WS, Chaudhri OB, Patterson M, et al: Kisspeptin-54 stimulates the hypothalamicpituitary gonadal axis in human males. J Clin Endocrinol Metab 2005;90:6609-6615.

-92 Smith JT, Cunningham MJ, Rissman EF, Clifton DK, Steiner RA: Regulation of Kiss1 gene expression in the brain of the female mouse. Endocrinology 2005; 146:36863692.

93 Smith JT, Dungan HM, Stoll EA, et al: Differential regulation of KiSS-1 mRNA expression by sex steroids in the brain of the male mouse. Endocrinology 2005; 146:29762984.

$\checkmark 94$ Licinio J, Mantzoros C, Negrao AB, et al: Human leptin levels are pulsatile and inversely related to pituitary-adrenal function. Nat Med 1997;3:575-579.

$\checkmark 95$ Smith JT, Acohido BV, Clifton DK, Steiner RA: KiSS-1 neurones are direct targets for leptin in the ob/ob mouse. J Neuroendocrinol 2006; 18:298-303.

-96 Welt CK, Chan JL, Bullen J, et al: Recombinant human leptin in women with hypothalamic amenorrhea. N Engl J Med 2004;351: 987-997.
$\$ 97$ Vaisse C, Halaas JL, Horvath CM, Darnell JE Jr, Stoffel M, Friedman JM: Leptin activation of Stat 3 in the hypothalamus of wildtype and ob/ob mice but not $\mathrm{db} / \mathrm{db}$ mice. Nat Genet 1996;14:95-97.

$\checkmark 98$ Montague CT, Farooqi S, Whitehead FP, et al: Congenital leptin deficiency is associated with severe early-onset obesity in humans. Nature 1997;387:903-908.

$\checkmark 99$ Strobel A, Issad T, Camoin L, Ozata M, Strosberg AD: A leptin missense mutation associated with hypogonadism and morbid obesity. Nat Genet 1998;18:213-215.

100 Gibson WT, Farooqi IS, Moreau M, et al: Congenital leptin deficiency due to homozygosity for the Delta133G mutation: report of another case and evaluation of response to four years of leptin therapy. J Clin Endocrinol Metab 2004;89:4821-4826.

101 Farooqi IS, Matarese G, Lord GM, et al: Beneficial effects of leptin on obesity, $T$ cell hyporesponsiveness, and neuroendocrine/ metabolic dysfunction of human congenital leptin deficiency. J Clin Invest 2002;110: 1093-1103.

102 Clement K, Vaisse C, Lahlou N, et al: A mutation in the human leptin receptor gene causes obesity and pituitary dysfunction. Nature 1998;392:398-401.

103 Licinio J, Caglayan S, Ozata M, et al: Phenotypic effects of leptin replacement on morbid obesity, diabetes mellitus, hypogonadism, and behavior in leptin-deficient adults. Proc Natl Acad Sci USA 2004;101: 4531-4536.

104 Faroogi IS, Wangensteen T, Collins S, et al: Clinical and molecular genetic spectrum of congenital deficiency of the leptin receptor. N Engl J Med 2007;356:237-247.

105 Muscatelli F, Strom TM, Walker AP, et al Mutations in the DAX-1 gene give rise to both X-linked adrenal hypoplasia congenita and hypogonadotropic hypogonadism. Nature 1994;372:672-676.

106 Zanaria E, Muscatelli F, Bardoni B, et al: An unusual member of the nuclear hormone receptor superfamily responsible for Xlinked adrenal hypoplasia congenita. Nature 1994;372:635-641.

107 Guo W, Mason JS, Stone CG, et al: Diagnosis of X-linked adrenal hypoplasia congenita by mutation analysis of the DAX1 gene. JAMA 1995;274:324-330.

108 Zhang Y-H, Guo W, Wagner RL, et al: DAX1 mutations provide insight into structure-function relationships in steroidogenic tissue development. Am J Hum Genet 1998;62:855-864.

109 Merke DP, Tajima T, Baron J, Cutler GB: Hypogonadotropic hypogonadism in a $\mathrm{fe}$ male caused by an X-linked recessive mutation in the DAX1 gene. N Engl J Med 1999; 340:1248-1252.
110 Seminara SB, Achermann JC, Genel M, Jameson JL, Crowley WF Jr: X-linked adrenal hypoplasia congenita: a mutation in DAX1 expands the phenotypic spectrum in males and females. J Clin Endocrinol Metab 1999;84:4501-4509.

111 Achermann JC, Gu WX, Kotlar TJ, et al: Mutational analysis of DAX1 in patients with hypogonadotropic hypogonadism or pubertal delay. J Clin Endocrinol Metab 1999;84:4497-4500.

112 Mantovani G, Ozisik G, Achermann JC, et al: Hypogonadotropic hypogonadism as a presenting feature of late-onset $\mathrm{x}$-linked adrenal hypoplasia congenita. J Clin Endocrinol Metab 2002;87:44-48.

113 Maier CC, Blalock JE: PCR-based cloning, sequencing, and exon mapping of lymphocyte derived neuroendocrine peptides. Immunomethods 1994;5:3-7.

114 Tabarin A, Achermann JC, Recan D, et al: A novel mutation in DAX1 causes delayedonset adrenal insufficiency and incomplete hypogonadotropic hypogonadism. J Clin Invest 2000;105:321-328.

115 Habiby RL, Boepple P, Nachtigall L, Sluss PM, Crowley WF Jr, Jameson JL: Adrenal hypoplasia congenita with hypogonadotropic hypogonadism: evidence that DAX-1 mutations lead to combined hypothalmic and pituitary defects in gonadotropin production. J Clin Invest 1996;98:1055-1062.

116 Caron P, Imbeaud S, Bennet A, Plantavid M, Camerino G, Rochiccioli P: Combined hypothalamic-pituitary-gonadal defect in a hypogonadic man with a novel mutation in the DAX-1 gene. J Clin Endocrinol Metab 1999;84:3563-3569.

- 117 Achermann JC, Silverman BL, Habiby RL, Jameson JL: Presymptomatic diagnosis of $\mathrm{X}$-linked adrenal hypoplasia congenita by analysis of DAX1. J Pediatr 2000;137:878881.

118 Wiltshire E, Couper J, Rodda C, Jameson JL, Achermann JC: Variable presentation of X-linked adrenal hypoplasia congenita. J Pediatr Endocrinol Metab 2001;14:10931096.

119 Achermann JC, Ito M, Silverman BL, et al: Missense mutations cluster within the carboxyl-terminal region of DAX-1 and impair transcriptional repression. J Clin Endocrinol Metab 2001;86:3171-3175.

120 Salvi R, Gomez F, Fiaux M, et al: Progressive onset of adrenal insufficiency and hypogonadism of pituitary origin caused by a complex genetic rearrangement within DAX-1. J Clin Endocrinol Metab 2002;87: 4094-4100.

-121 Ozisik G, Mantovani G, Achermann JC, et al: An alternate translation initiation site circumvents an amino-terminal DAX1 nonsense mutation leading to a mild form of X-linked adrenal hypoplasia congenita. J Clin Endocrinol Metab 2003;88:417-423. 
122 Lin L, Gu WX, Ozisik G, et al: Analysis of DAX1 (NR0B1) and steroidogenic factor-1 (NR5A1) in children and adults with primary adrenal failure: ten years' experience. J Clin Endocrinol Metab 2006;91:30483054.

$\checkmark 123$ Achermann JC: The role of SF1/DAX1 in adrenal and reproductive function. Ann Endocrinol (Paris) 2005;66:233-239.

- 124 Yu RN, Ito M, Saunders TL, Camper SA, Jameson JL: Role of Ahch in gonadal development and gametogenesis. Nat Genet 1998;20:353-357.

- 125 Jackson RS, Creemers JW, Ohagi S, et al: Obesity and impaired prohormone processing associated with mutations in the human prohormone convertase 1 gene. Nat Genet 1997;16:303-306.

126 O’Rahilly S, Gray H, Humphreys PJ, et al: Brief report: impaired processing of prohormones associated with abnormalities of glucose homeostasis and adrenal function. N Engl J Med 1995;333:1386-1390.

- 127 Jackson RS, Creemers JW, Farooqi IS, et al: Small-intestinal dysfunction accompanies the complex endocrinopathy of human proprotein convertase 1 deficiency. J Clin Invest 2003;112:1550-1560.

128 Dattani MT, Martinez-Barbera J-P, Thomas PQ, et al: Mutations in the homeobox gene HESX1/Hesx1 associated with septooptic dysplasia in human and mouse. Nat Genet 1998;19:125-133.

-129 Thomas PQ, Dattani MT, Brickman JM, et al: Heterozygous HESX1 mutations associated with isolated congenital pituitary hypoplasia and septo-optic dysplasia. Hum Mol Genet 2001;10:39-45.

-130 Brickman JM, Clements M, Tyrell R, et al: Molecular effects of novel mutations in Hesx1/HESX1 associated with human pituitary disorders. Development 2001;128: 5189-5199.

-131 Quirk J, Brown P: Hesx1 homeodomain protein represses transcription as a monomer and antagonises transactivation of specific sites as a homodimer. J Mol Endocrinol 2002;28:193-205.

-132 Kim SS, Kim Y, Shin YL, Kim GH, Kim TU, Yoo HW: Clinical characteristics and molecular analysis of PIT1, PROP1,LHX3, and HESX1 in combined pituitary hormone deficiency patients with abnormal pituitary MR imaging. Horm Res 2003;60:277-283.

-133 Carvalho LR, Woods KS, Mendonca BB, et al: A homozygous mutation in HESX1 is associated with evolving hypopituitarism due to impaired repressor-corepressor interaction. J Clin Invest 2003;112:11921201.

134 Cohen RN, Cohen LE, Botero D, et al: Enhanced repression by HESX1 as a cause of hypopituitarism and septooptic dysplasia. J Clin Endocrinol Metab 2003;88:48324839.
135 Reynaud R, Gueydan M, Saveanu A, et al: Genetic screening of combined pituitary hormone deficiency: experience in 195 patients. J Clin Endocrinol Metab 2006;91: 3329-3336.

136 Fluck C, Deladoey J, Rutishauser K, et al: Phenotypic variability in familial combined pituitary hormone deficiency caused by a PROP1 gene mutation resulting in the substitution of Arg to Cys at codon 120 (R120C). J Clin Endocrinol Metab 1998;83: 3727-3734.

137 Cogan JD, Wu W, Phillips JAI, et al: The PROP1 2-base pair deletion is a common cause of combined pituitary hormone deficiency. J Clin Endocrinol Metab 1998;83: 3346-3349.

138 Wu W, Cogan JD, Pfaffle RW, et al: Mutations in PROP1 cause familial combined pituitary hormone deficiency. Nat Genet 1998;18:147-149.

139 Arroyo A, Pernasetti F, Vasilyev VV, Amato P, Yen SS, Mellon PL: A unique case of combined pituitary hormone deficiency caused by a PROP1 gene mutation (R120C) associated with normal height and absent puberty. Clin Endocrinol (Oxf) 2002;57:283291

140 Park JK, Ozata M, Chorich LP, et al: Analysis of the PROP1 gene in a large cohort of patients with idiopathic hypogonadotropic hypogonadism. Clin Endocrinol (Oxf) 2004;60:147-149.

141 Andersen B, Pearse RV 2nd, Jenne K, et al: The Ames dwarf gene is required for Pit-1 gene activation. Dev Biol 1995;172:495503.

142 Kelberman D, Rizzoti K, Avilion A, et al: Mutations within Sox2/SOX2 are associated with abnormalities in the hypothalamopituitary-gonadal axis in mice and humans. J Clin Invest 2006;116:2442-2455

143 Laumonnier F, Ronce N, Hamel BC, et al: Transcription factor SOX3 is involved in Xlinked mental retardation with growth hormone deficiency. Am J Hum Genet 2002;71: 1450-1455.

144 Woods KS, Cundall M, Turton J, et al: Overand underdosage of SOX3 is associated with infundibular hypoplasia and hypopituitarism. Am J Hum Genet 2005;76:833849.

145 Rizzoti K, Brunelli S, Carmignac D, Thomas PQ, Robinson IC, Lovell-Badge R: SOX3 is required during the formation of the hypothalamo-pituitary axis. Nat Genet 2004; 36:247-255.

146 Netchine I, Sobrier ML, Krude H, et al: Mutations in LHX3 result in a new syndrome revealed by combined pituitary hormone deficiency. Nat Genet 2000;25:182-186.

147 Sloop KW, Parker GE, Hanna KR, Wright HA, Rhodes SJ: LHX3 transcription factor mutations associated with combined pituitary hormone deficiency impair the activation of pituitary target genes. Gene 2001; 265:61-69.
148 Machinis K, Pantel J, Netchine I, et al: Syndromic short stature in patients with a germline mutation in the LIM homeobox LHX4. Am J Hum Genet 2001;69:961-968.

149 Tajima T, Hattori T, Nakajima T, Okuhara K, Tsubaki J, Fujieda K: A novel missense mutation (P366T) of the LHX4 gene causes severe combined pituitary hormone deficiency with pituitary hypoplasia, ectopic posterior lobe and a poorly developed sella turcica. Endocr J 2007;54:637-641.

150 Layman LC, Edwards JL, Osborne WE, et al: Human chorionic gonadotropin-b sequences in women with disorders of HCG production. Mol Hum Reprod 1997;3:315320.

-151 Weiss J, Adams E, Whitcomb RW, Crowley WF Jr, Jameson JL: Normal sequence of the gonadotropin-releasing hormone gene in patients with idiopathic hypgonadotropic hypogonadism. Biol Reprod 1991;45:743747.

152 Valdes-Socin H, Salvi R, Daly AF, et al: Hypogonadism in a patient with a mutation in the luteinizing hormone beta-subunit gene. N Engl J Med 2004;351:2619-2625.

$\checkmark 153$ Lofrano-Porto A, Barra GB, Giacomini LA, et al: Luteinizing hormone beta mutation and hypogonadism in men and women. $\mathrm{N}$ Engl J Med 2007;357:897-904.

154 Layman LC, Lee EJ, Peak DB, et al: Delayed puberty and hypogonadism caused by a mutation in the follicle stimulating hormone $\beta$-subunit gene. N Engl J Med 1997; 337:607-611.

155 Layman LC, Porto AL, Xie J, et al: FSH beta gene mutations in a female with partial breast development and a male sibling with normal puberty and azoospermia. J Clin Endocrinol Metab 2002;87:3702-3707.

156 Matthews CH, Borgato S, Beck-Peccoz P, et al: Primary amenorrhea and infertility due to a mutation in the $\beta$-subunit of folliclestimulating hormone. Nat Genet 1993;5: 83-86.

157 Clark AD, Layman LC: Analysis of the Cys82Arg mutation in follicle-stimulating hormone beta (FSHbeta) using a novel FSH expression vector. Fertil Steril 2003;79: 379-385.

158 Lindstedt G, Nystrom E, Matthews C, Ernest I, Janson PO, Chatterjee K: Follitropin (FSH) deficiency in an infertile male due to FSHbeta gene mutation: a syndrome of normal puberty and virilization but underdeveloped testicles with azoospermia, low FSH but high lutropin and normal serum testosterone concentrations. Clin Chem Lab Med 1998;36:663-665.

159 Phillip M, Arbelle JE, Segev Y, Parvari R: Male hypogonadism due to a mutation in the gene for the b-subunit of follicle stimulating hormone. N Engl J Med 1998;338: 1729-1732. 
-160 Barnes RB, Namnoum A, Rosenfield RL, Layman LC: Effects of follicle-stimulating hormone on ovarian androgen production in a woman with isolated follicle-stimulating hormone deficiency. N Engl J Med 2000;343:1197-1198.

-161 Barnes RB, Namnoum A, Rosenfield RL, Layman LC: The role of LH and FSH in ovarian androgen secretion and ovarian follicular development: Clinical studies in a patient with isolated FSH deficiency and multicystic ovaries. Hum Reprod 2002;17: 88-91.

162 Vissers LE, van Ravenswaaij CM, Admiraal $\mathrm{R}$, et al: Mutations in a new member of the chromodomain gene family cause CHARGE syndrome. Nat Genet 2004;36: 955-957.

163 Hurst JA, Meinecke P, Baraitser M: Balanced $t(6 ; 8)(6 p 8 p ; 6 q 8 q)$ and the CHARGE association. J Med Genet 1991;28:54-55.

-164 Lalani SR, Safiullah AM, Fernbach SD, et al: Spectrum of CHD7 mutations in 110 individuals with CHARGE syndrome and genotype-phenotype correlation. Am J Hum Genet 2006;78:303-314.

-165 Sanlaville D, Etchevers HC, Gonzales M, et al: Phenotypic spectrum of CHARGE syndrome in fetuses with CHD7 truncating mutations correlates with expression during human development. J Med Genet 2006; 43:211-217.

-166 Jongmans MC, Admiraal RJ, van der Donk $\mathrm{KP}$, et al: CHARGE syndrome: the phenotypic spectrum of mutations in the CHD7 gene. J Med Genet 2006;43:306-314.

-167 Sanlaville D, Verloes A: CHARGE syndrome: an update. Eur J Hum Genet 2007; 15:389-399.

- 168 Bosman EA, Penn AC, Ambrose JC, Kettleborough R, Stemple DL, Steel KP: Multiple mutations in mouse Chd7 provide models for CHARGE syndrome. Hum Mol Genet 2005; 14:3463-3476.

-169 Hurd EA, Capers PL, Blauwkamp MN, et al: Loss of Chd7 function in gene-trapped reporter mice is embryonic lethal and associated with severe defects in multiple developing tissues. Mamm Genome 2007;18: 94-104.
170 Chalouhi C, Faulcon P, Le Bihan C, HertzPannier L, Bonfils P, Abadie V: Olfactory evaluation in children: application to the CHARGE syndrome. Pediatrics 2005;116: e81-e88.

171 Pinto G, Abadie V, Mesnage R, et al: CHARGE syndrome includes hypogonadotropic hypogonadism and abnormal olfactory bulb development. J Clin Endocrinol Metab 2005;90:5621-5626.

172 Ogata T, Fujiwara I, Ogawa E, Sato N, Udaka T, Kosaki K: Kallmann syndrome phenotype in a female patient with CHARGE syndrome and CHD7 mutation. Endocr J 2006;53:741-743.

173 Kramer PR, Wray S: Novel gene expressed in nasal region influences outgrowth of olfactory axons and migration of luteinizing hormone-releasing hormone (LHRH) neurons. Genes Dev 2000;14:1824-1834.

174 Miura K, Acierno JS Jr, Seminara SB: Characterization of the human nasal embryonic LHRH factor gene, NELF, and a mutation screening among 65 patients with idiopathic hypogonadotropic hypogonadism (IHH). J Hum Genet 2004;49:265-268.

175 Pitteloud N, Quinton R, Pearce S, et al: Digenic mutations account for variable phenotypes in idiopathic hypogonadotropic hypogonadism. J Clin Invest 2007;117:457463.

176 Matsumoto S, Yamazaki C, Masumoto KH, et al: Abnormal development of the olfactory bulb and reproductive system in mice lacking prokineticin receptor PKR2. Proc Natl Acad Sci USA 2006;103:4140-4145.

177 Dode C, Teixeira L, Levilliers J, et al: Kallmann syndrome: mutations in the genes encoding prokineticin- 2 and prokineticin receptor-2. PLoS Genet 2006;2:e175.

178 Best LG, Wasdahl WA, Larson LM, Sturlaugson J: Chromosome abnormality in Kallmann syndrome. Am J Med Genet 1990;35:306-309.
179 Guioli S, Incerti B, Zanaria E, et al: Kallmann syndrome due to a translocation resulting in an X/Y fusion gene. Nat Genet 1992;1:337-340

180 Casamassima AC, Wilmot PL, Vibert BK, Shapiro LR: Kallmann syndrome associated with complex chromosome rearrangement. Am J Med Genet 1993;45:539-541.

181 Kikuchi I, Nagamine M, Ueda A, Mihara K, Seita M, Minoda M: Chromosomal translocation $\mathrm{t}(13 ; 16)$ in a patient with idiopathic hypogonadotropic hypogonadism. Intern Med 1993;32:465-467.

182 Elbistan M, Aydin M, Bagci H, Kara N: A case of hypogonadism with a translocation: $\mathrm{t}(4 ; 12)$ (q25; q24.2). Indian J Pediatr 1994; 61:421-426.

183 Schinzel A, Lorda-Sanchez I, Binkert F, et al: Kallmann syndrome in a boy with a $\mathrm{t}(1$; 10) translocation detected by reverse chromosome painting. J Med Genet 1995;32: 957-961.

184 Kroisel PM, Petek E, Wagner K, Kurnik P: Complex chromosomal translocation in a patient with Kallmann syndrome. Am J Med Genet 2000;91:240.

185 Vermeulen S, Messiaen L, Scheir P, De Bie S, Speleman F, De Paepe A: Kallmann syndrome in a patient with congenital spherocytosis and an interstitial 8p11.2 deletion. Am J Med Genet 2002;108:315-318.

186 Helszer Z, Lach J, Nowacka J, Constantinou M, Kaluzewski B: Inv(10) in a patient with hypogonadotropic hypogonadism. J Appl Genet 2003;44:225-229.

- 187 Talaban R, Sellick GS, Spendlove HE, et al: Inherited pericentric inversion $(X)(\mathrm{p} 11$. 4q11.2) associated with delayed puberty and obesity in two brothers. Cytogenet Genome Res 2005;109:480-484.

188 Kim HG, Herrick SR, Lemyre E, Kishikawa S, Salisz JA, Seminara S, MacDonald ME, Bruns GA, Morton CC, Quade BJ, Gusella JF: Hypogonadotropic hypogonadism and cleft lip and palate caused by a balanced translocation producing haploinsufficiency for FGFR1. J Med Genet 2005;42: 666-672. 